\title{
Kent Hastanelerinde Açık Alan Kullanım İhtiyaçlarının Belirlenmesi ve Açık Alan Tasarım İlkeleri
}

*

\author{
Nilüfer Gürer \\ Akdeniz Üniversitesi
}

Öz

Hastaneler, temel işlevlerine odaklanarak kişilere tedavi öncelikli hizmet vermektedir. Bu nedenle hastanelerde, çalışan doktorlarm nitelik ve niceliklerinin yanı sıra, kişilere tedavi sırasında sunulacak hizmet kalitesi, teknolojik yeniliklere ulaşma imkânı ve mekânsal konfor sunumu önemsenmektedir. Ancak, hastane açık alanları, hasta ve yakınlarının gerek fiziksel gerek ruhsal sağlıkları açısından önem arz etmekte, ancak açık alanlara tedavi süreçlerinde öncelikli konular arasında yeterince yer verilmemektedir. Yoğun bir kullanıcı / hasta grubu olan sağlık kampüslerinde sunulan hizmet kalitesinin yanı sıra mekânsal nitelikler de önem kazanmaktadır. Bu bakış açısı ile çalışma kapsamında, yeni ek binaların inşası ve yapı ömrünü doldurmuş eski binaların dönüşümü ile yapılı alanların yeniden ele alınacă̆ı Gazi Üniversitesi Hastanesi açık alanlarının bu süreçte kullanıcıları açısından ihtiyaçları karşılayabilecek şekilde nasıl daha doğru ve verimli biçimde tasarlanabileceği konusu ele alınmıştır. Çalışmada hastanedeki temel kullanıcı gruplarına (akademik personel ve çalışanlar, hasta ve hasta yakınları ile öğrenciler) anketler yapılmış, her bir farklı kullanıcı grubunun ihtiyaçları belirlenerek, bu ihtiyaçların dikkate alındığı, yeni açık yeşil mekânlar yaratmada etkili olabilecek temel gereklilikler detaylandırılmaya çalışılmıştır. Elde edilen bulgulara göre, farklı kullanıcı gruplarımın hastane açı alanlarını, bulundukları zaman dilimleri ve süreleri farklı olmasına rağmen, temelde benzer ihtiyaçlar için kullandıkları ve bunda dinlenme, yeme içme ve hastane koşullarından bir nebze de olsa uzaklaşarak doğa ile bütünleşme ihtiyaçlarını gidermenin yattığı belirlenmiştir.

Anahtar kelimeler: Kent hastaneleri, hastane açık alanları, tasarım ilkeleri

idealkent @ Kent Araştırmaları Dergisi (Journal of Urban Studies)

http://idealkentdergisi.com

Geliş Tarihi Received Date: 18.07.2018 Kabul Tarihi Accepted Date: 24.08.2018 


\title{
Determining the Needs of use and Design Principles of Open Spaces in Urban Hospitals
}

*

\author{
Nilüfer Gürer \\ Akdeniz University
}

\begin{abstract}
Hospitals offer mainly treatment services to people as their basic functions. The qualifications and quantities of doctors working in the hospitals as well as the service quality, accessibility to the technological innovations and providing comfortable places are therefore the essential issues taken primarily into consideration in the hospitals. However, even though open spaces in the hospitals occupy a significant place for both physical and emotional health of patients and their relatives, they are not adequately given a significant place in the prior subjects of treatment processes. Issue of the service quality provided in the health campuses, which have intensive users / patient groups, has come into prominence along with the issue of spatial qualities. In this sense, within the scope of this study, open spaces of Gazi University Hospital, in which a partial transformation process has been undergoing, including the construction of additional buildings and the demolition of old buildings, are selected as a case with the aim of discussing how they can be designed in a proper and efficient manner to meet the demands and to satisfy the expectations of the users. In this study, questionnaires are conducted to the main user groups in the hospital (academic and working staff, patients and their relatives, and students) in order to put forward the factors that could be crucial in creating new open spaces by determining and considering the essential needs and expectations of each and every group. Given the findings, it is determined that, despite their differences in durations and time spent, each user group uses the open spaces in the hospital for similar reasons including resting, eating and drinking, and distancing themselves from the usual hospital conditions by communing with the nature.
\end{abstract}

Keywords: Urban hospitals, hospital open spaces, design principles 


\section{Giriş}

Farklı pek çok boyutu olan (hasta bakımı, hastalıkların teşhis ve tedavisi, idari hizmetler, eğitim vb.) sağlık hizmetleri, yapıları gereği, mekânsal olarak ayrıştırılamadıkları için genelde aynı bina içerisinde ya da bir yapılar bütünü (sağlık kompleksi, sağlık kampüsü gibi) içerisinde sunulmaktadır. Sağlık yapılarında en temel hizmet olan hasta kabul, hastalık teşhis ve tedavi süreçlerinde binaların bulunduğu mekânın kalitesi ve binaların mimari nitelikleri hastaların iyileşme sürecinin önemli bir parçasıdır. Dolayısıyla içinde bulunulan fiziksel nitelikler sunulan sağlık hizmetlerinin sonuçlarını da etkilemektedir.

Hastane yapılarının zamansal gelişim ve değişimi incelendiğinde, ilk inşa edildiklerinde ücretsiz hizmet veren, koğuşlar şeklinde düzenlenen hasta odalarının yer aldığı, tek katlı yapılar / barakalar olarak tasarlandıkları görülmektedir. Bu hastanelerde hasta sayılarının koğuşlarda kimi zaman 100 kişiyi bulması, aynı yatakta iki hastanın yatırılması, karanlık ve iyi havalandırılmayan, bir başka anlatımla hijyen koşullarının yeterince iyi olmadığı ortamlarda hastalıkların hızla yayılması, salgın hastalıkların artması çok ciddi problemler yaratmaya başlamış ve bu düzene alternatif yeni arayışlar içine girilmiştir. Bu arayışlar ile getirilen ilk çözüm önerisi temiz havanın ve gün ışığının hastane içine girmesini sağlayan, böylece hastaların iyileşme süreçlerini hızlandıran ve salgın hastalıkların azalmasında etkili olan pavilyon planlı hastane tasarımıdır ve bu tasarım ilk kez 1854 yılında Fransa' da Lariboisiere Hastanesinde uygulanmıştır. Ancak bu yeni plan sisteminde de çok sayıda hastanın bir arada yatırıldığı koğuş düzeni devam etmiştir. 1800lerin sonunda Londra' da ilk ücretli hastaneler açılmış, tek kişilik odaların olduğu yeni yapılar inşa edilmiş, 1900lü yılların başında ise özel oda sayılarının artmasıyla birlikte, arazi kullanım oranını düşürmek ve yolculuk mesafelerini azaltmak amacıyla çok katlı hastane yapıları tasarlanmaya başlamıştır (Gormley, 2010, s.50-54). 1990lardan sonra ise hastane yapılarının inşasında ofis birimleri, idari birimler ve hasta tedavi birimleri bir arada ele alınmaya başlanmış, yüksek katlı yapılarda tüm sağlık hizmetlerinin bir arada sunumu hedeflenmiştir. Özellikle 2. Dünya savaşı sonrasında yüksek katlı yapıların maliyet etkin olması ve sundukları avantajlı durumlar sebebiyle (hizmetlerin bir arada sunulması, farklı birimlere kolay erişebilme vb.) bu yeni sunum biçimi çok katlı sağlık komplekslerini gündeme getirmiştir. Ancak bu yüksek yapılı yeni düzende, peyzaj düzenlemeleri hastanelerin giriş mekânlarının düzenlenmesi olarak ele alınmış, bu yaklaşım da yeşil terasların ve yeşil bahçelerin 
yok olmasına, doğal havalandırmanın yerini klima sistemlerinin almasına, açık yeşil alanlar yerine araba park alanlarının konulmasına neden olmuş, bu süreç de hastalar ve diğer hastane kullanıcıları için daha stresli ortamların yaratılmasına sebebiyet vermiştir (Marcus, 2007, s.1).

$\mathrm{Bu}$ yeni yapılanmada prestijli kent hastanelerinin öncü olması, diğer hastane yapılarına örnek oluşturmuş, zaman içerisinde sağlık yapıları yavaş yavaş tek yapı ölçeğinde hizmet sunan, açık yeşil alanlarla ilişkisi en az seviyeye inmiş, kişilerin dış mekânlar ile kuracakları aktif ya da pasif ilişkinin insan/hasta psikolojisi üzerindeki etkilerini göz ardı eden, nitelikli ve kaliteli sunumu yapı içinde verilen hizmetlerle ölçen, rekabete dayalı bir sistem yaratılmıştır. Bu sistemde az da olsa hekimler, hastalar, hasta yakınları ve hastane personeli için stres azaltıcı ve dinlendirici mekanların (çatı bahçeleri, yeşil avlular, terapi bahçeleri vb.) tasarlandığı da söylenebilir (Marcus ve Francis, 1997, s.311). Ancak genel yapısı itibariyle sağlık sektöründeki hızlı değişim ile son teknolojilere sahip tıbbi aletlerin geliştirilmesi, ilaç endüstrisinin hızlı yükselişi, özelleşmiş sağlık hizmetlerinin sunumu gibi etkiler açık alanların yapılandırıcı yararlarının göz ardı edilmesine de sebep olmaktadır. Buna karşın literatürde açık ve yeşil alanların insan psikolojisi ve insan sağlığı üzerindeki etkilerini araştıran ve bu alanların kişilerin akıl ve ruh sağlı̆̆ üzerindeki pozitif etkilerini ortaya koyan pek çok çalışma bulunmaktadır (Abbas ve Ghazali, 2011, s.1951; Bengtsson ve Grahn, 2014, s.879; Hartig, 1993, s.23; Hartig vd., 1991, s.7; Huisman vd. 2012, s.70; Mourshed ve Zhao, 2012, s.362; Ulrich 1981, s.524, 1984, s.420, 1992, s.97).

Hastaneler, özellikle kent ölçeğinde ve bölgesel ölçekte hizmet edenler, birçok farklı birimi ve işlevi bünyesinde barındırmaktadır. Bu işlevlerin her biri farklı mekânsal ihtiyaçlar doğurmakta, farklı kullanıcı gruplarını bir araya getirmekte, dolayısıyla farklı açık alan gereksinimlerini de ortaya çıkarmaktadır. Ancak hızla artan yapılaşma ve özel araç kullanımı hastane açık alanlarının çoğu zaman giriş-çıkış ve otopark alanları olarak kullanılmasına sebep olmakta ve açık alanların rekreatif ihtiyaçları karşılama ve tedavi süreci içerisindeki yardımcı işlevi göz ardı edilmekte, hızlı mekân çözümleriyle anlık ihtiyaçların karşılanması temel hedef olmaktadır. Bu problemden yola çıkılarak makalede, yoğun kentsel yerleşim dokusunda yer alan hastanelerde kullanıcıların açık alan ihtiyaçlarının tanımlanması ve bu ihtiyaçların karşılanmasına yönelik olarak, farklı örnekler açısından da uygulanabilir, tasarım ilke, hedef ve yöntemlerinin ortaya konması hedeflenmiştir. 
Bu amaca yönelik olarak ilk bölümde literatür araştırmaları ile hastane açık alanlarının insan sağlığı üzerindeki etkileri ve bu alanların tedavi süreçlerine katkıları konularına değinilmiştir. İkinci bölümde hastanelerdeki farklı kullanıcı grupları ve bu grupların farklılaşan açı alan ihtiyaçları ele alınarak, her bir grup için temel işlevsel alanlar belirlenmeye çalışılmış ve ihtiyaçlara göre açık alan tasarım kriterleri sıralanmıştır. Bulgular ve tartışma bölümlerinde örnek alan olarak ele alınan Gazi Üniversitesi Hastanesi'nde kullanıcılar için sunulan açık alan yetersizliklerine değinilerek, literatür araştırmaları ile tanımlanan kriterlerin ne kadar karşılanabildiği analiz edilmiş, anketler ile elde edilen bulgular üzerinden eksik olduğu düşünülen düzenlemeler için alana özel öneriler geliştirilmeye çal1şılmıştır. Sonuç bölümünde ise kentsel doku içerisinde yer alan sağlık alanları ve özelde hastaneler için açı alan ihtiyaçları ele alınarak, kullanıcı ihtiyaçlarının karşılanmasına yönelik minimum gereklilikler vurgulanmaya çalışılmıştır. Makalenin, eş zamanlı olarak, hastane kampüs alanında kullanım ömrünü doldurmuş yapıların yıkılması ile birlikte açık alan ihtiyacını karşılamaya yönelik olarak yaratılan fırsatı değerlendirmede fikir verici ve uygulamaya yönelik kararların alınmasında kolaylaştırıcı olacağı da düşünülmektedir.

\section{Hastaneler ve Açık Alan Düzenlemeleri}

Sağlık hizmeti vermek amaçlı, gerektiğinde hastaların yatarak gerektiğinde ayakta tedavi oldukları kapalı ve açık mekânları bulunan kamusal mekânlara sağlık alanları denmektedir. Dünya Sağlık Örgütü tarafından; belli bir sistematik ve kurumsal düzen içerisinde 7 gün 24 saat aralıksız biçimde hizmet verilen, sağlık konusunda uzman personel ile yardımcı personelin bir arada yer aldığı, tıbbi hizmetlerin ve bununla bağlantılı bakım hizmetlerinin sunulduğu sağlık birimleri hastane olarak tanımlanmaktadır (WHO, 2018).

$\mathrm{Bu}$ alanlar farklı ölçekte ve bünyesinde bulundurduğu birimlere (eğitim ve araştırma, kadın doğum ve çocuk hastanesi vb.) göre farklı kimlikte olabilmektedir. Yıllar içerisinde değişen teknolojiler ile birlikte sağlık alanlarının da değişime uğradığ̣ gözlenmektedir. Bu değişim ilkel toplumlardan günümüze kadar farklı boyutlarda, farklı niteliklerde gerçekleşmiş, ilkel dönemde tanrıların iyileştirici olduğu inancı ile tapınaklara yapılan ziyaretler ve din adamlarının farklı tedavi yöntemleri geçerli kabul edilirken, zaman içerisinde artan bilgi birikimi ve gelişen teknolojilerle birlikte modern hastanelere kadar yaşanan bir değişim izlenmiştir. Bu değişim sadece mekânsal olarak yaşanmamış, eş zamanlı olarak kişilerin 
hastanelerden aldıkları hizmetlerden beklentilerini de zaman içerisinde şekillendirmiştir. Değişen ve gelişen teknolojiler bilgiye erişimi kolaylaştırmış, deneyimlerin ve bilginin paylaşımı halkın sağlık konusunda daha bilinçli olmasına ve sunulan hizmetleri sorgulamalarına da sebep olmuştur (Francis ve Marcus, 1997, s. 311 ).

Dünya Sağlık Örgütü'ne göre "sağlık"; bireyin yalnızca herhangi bir hastalığının olmaması durumu değil aynı zamanda da fiziksel, ruhsal ve sosyal açılardan da "kendini iyi hissetme", "memnun olma" durumu olarak tanımlanmaktadır. Bireyin sağlıklı olma durumu, toplum sağlığını doğrudan etkilemektedir. Birey ya da toplumun ruhsal, fiziksel ve sosyal anlamda sağlıklı olması büyük oranda; fiziksel çevrenin (alan kullanımı ve kentsel tasarım kararlarının) halkın iyi olma halini destekler nitelikte olması ile gerçekleştirilebilir (Uslu, Kiper ve Barış, 2009, s.1399). Tasarlanmış ve estetik bir çevrenin insan psikoloji üzerinde etkileriyle hastalıkların tedavi süreci değişebilmektedir. Kurgusu yanlış yapılmış alanların tedavi sürecine olumsuz etkileri olabileceği gibi doğru kurgulanmış alanlar da tedavi sürecini hızlandırabilmektedirler.

Sağlık komplekslerinde açık ve yeşil alan kullanımlarına ilişkin farklı yaş gruplarını kapsayacak şekilde araştırmalar yapılmış, farklı yerlerde yaşayan ve farklı sağlık problemleri olan hastaların doğaya erişilebilen, doğa ile etkileşim kurulmasını sağlayabilen fiziksel mekânların (balkonlar, bahçeler, açık yeşil alanlara bakan pencereler, iç mekân bitkileri ve/veya doğa resimleri vb.) yaratılması gerekliliği elde edilen ortak görüş olarak ortaya çıkmıştır. Ayrıca kişilere stres altında ya da mutsuz olduklarında ne yapmayı tercih ettikleri sorulmuş, kişiler bu gibi durumlarda açık yeşil alanlara, dış mekânlara ya da tasarlanmış/düzenlenmiş mekânlara gitmeyi tercih ettiklerini dile getirmişlerdir (Marcus ve Barnes, 1999, s.5). Hastane alanlarının tasarlanmasında sadece yapı ölçeğinde değil, yapının yakın çevresinde yer alan açık alan düzenlemeleri konularında da toplumsal ihtiyaçların karşılanmasına yönelik kararlar alınmasının tedavi süreçlerinde hızlandırıcı ve katkı sağlayıcı etkiler yaratacağı dikkate alınması gereken bir durumdur.

\section{Hastane Kullanıcı Grupları ve Açık Alan İhtiyaçlanı}

Kamusal mekânlar olarak hizmet veren hastane ve sağlık komplekslerinde temelde üç farklı kullanıcı grubundan bahsetmek mümkündür. $\mathrm{Bu}$ gruplardan ilki hastanelerin daimi personeli olan doktorlar, sağlık perso- 
neli ve idari personel, ikincisi hastalar ve üçüncüsü de refakatçi ve ziyaretçiler olarak tanımlanabilir. Her bir kullanıcı grubu için farklı kullanım biçimleri farklı ihtiyaçlar doğurur. Sağlık yapılarında açık alan kullanımına ilişkin yapılan araştırmalar ve gözlemler bu alanları en çok çalışanların/personelin (bireysel veya grup olarak) kullandığını göstermektedir. $\mathrm{Bu}$ kullanıcı grubunu hastalar ve onlara eşlik eden ziyaretçiler takip etmekte, en az kullananlar ise refakatçisi/yakını olmayan yalnız hastalar olarak ortaya çıkmaktadır (Marcus ve Francis, 1997, s.311; Epstein, 2013). Farklılaşan kullanıcı gruplarına yönelik ihtiyaçların ve kullanım biçimlerinin tanımlaması bu alanların tasarlanmasındaki farklılıkları da ortaya koyacak ve tasarım ilkelerinin belirlenmesinde yönlendirici olacaktır.

\section{Hekimler, Sağlık Personeli ve İdari Personel}

Hastane personeli, mesai saatlerini hastanede geçirdikleri için açık alanların en önemli kullanıcılarıdır. Yapılan araştırmalar hastane bahçelerini kullanan kullanıcıların \%60'ının hastane personeli olduğunu belirtmektedir (Epstein, 2013). İdari personelin diş mekânları kullanmak için gerek öğle tatillerinde gerekse dinlenme zamanlarında sahip oldukları zaman aralığı, diğer personel grubuna nazaran (hekimler ve sağlık personeli) daha geniştir. Hekimler ve sağlık personeli hastanede bulundukları zamanın büyük kısmını tedavi amaçlı olarak hastalarla ilgilenerek geçirdikleri için açık alan kullanım olanaklarının daha sınırlı olduğu söylenebilir. Hekimlerin hastane açık alanlarını kullanımlarındaki temel amaç dinlenmektir, bunu yemek ve sohbet aktiviteleri takip etmektedir (Marcus ve Francis, 1997, s.312; Epstein, 2013). Bunula beraber hekimlerin açık alan kullanımının hastalar üzerindeki olumlu etkilerini bilmeleri çok önemlidir, çünkü hastaların bu alanları kullanıp kullanamayacağı kararını hekimler vermektedir (Marcus ve Francis, 1997, s.312).

Hastane açık alanları (hastane bahçeleri) her grup için mahremiyet içermelidir. Farklı gruplar dinlenme saatlerinde diğger gruplar ile bir arada olmak istemeyebilirler (personelin, yönetici ve hekimler ya da hastalar ile bir arada olmak istememesi, ya da hekimlerin de benzer şekilde diğer kullanıcı grupları ile bir arada olmak istememesi gibi). Bu nedenle açı alanlar tasarlanırken tüm grupların birbirlerinin mahremiyetine saygı gösterebilecekleri farklı mekânsal düzenlemeleri içermeleri de beklenmektedir.

\section{Hastalar}

Hastaların sağlık durumu dış mekânları kullanma kabiliyetlerini/olanaklarını da tanımlamaktadır. Herhangi bir tıbbi alete (izleme monitörü gibi) 
bağlı olmayan ve bağımsız olarak (tek başına) hareket kabiliyeti olan, uzun süreli tedavi gören hastalar hastane açık alanlarını daha çok kullanma eğilimindedirler. Ancak bu diğer hastaların bu alanları kullan(a)madığı anlamina gelmemektedir. Hareket kabiliyeti sınırlı olan, hareket edebilmesi herhangi bir alete ya da bir başka kişiye bağımlı olan hastalar için bu alanların kullanımı onlara yardımcı olabilecek personelin ya da gönüllü ziyaretçilerin varlığına bağlıdır (Marcus ve Francis, 1997, s.312).

\section{Refakatçi ve Ziyaretçiler}

Hastanede kalan hastalar için, onlara refakat eden yakınları ve tedavi süreçlerindeki aile ve arkadaş ziyaretleri gerek süreci kolay atlatmaları bakımından gerekse ruhsal sağlıkları açısından son derece önemlidir. Bu ziyaretler hastalara normal hayatın sürdügü hissini verdiği için kısa süreli de olsa kişilerin ve ziyaretçilerin hastane psikolojisinden çıkmalarına, karşlıklı olarak rahatlamalarına yardımcı olmaktadır.

Hasta odaları genellikle, işlevleri gereği, refakatçiler ve ziyaretçiler açısından konfor koşulları öncelikli olarak düşünülmüş şekilde değil, hastalara gerekli ve yeterli sağlık hizmetlerini sunabilecek büyüklüklerde tasarlanmaktadır. Bu nedenle de özellikle ziyaretçilerin bir araya gelip gerek hastalarla, gerek birbirleriyle, gerekse refakatçilerle uzun süreli sohbetlerine olanak verecek uygunluktaki mekânlar değillerdir. Benzer şekilde işlevleri açısından koridorlar ve sterilizasyon açısından da kafeteryalar hastalar ile görüşmeye çok uygun mekânlar olamayabilirler. Bu gibi durumlarda hasta, refakatçi ve ziyaretçilerin bir araya gelebilecekleri, havalandırma, ışık, sıcaklık, konfor vb. nitelikler açısından uygun alanların yaratılması, iklim koşullarının uygun olduğu bölgelerde bu mekânların açık ve yeşil alanlar olarak düzenlenmesi, fiziksel konforun yanı sıra psikolojik olarak da rahatlatıcı etkiler yaratmaktadır.

Hastanelerde açı alan ihtiyacı yaratan bir diğer zaman aralığı hasta yakınlarının ameliyatlar ya da tedavi süreçlerinde hastaları bekledikleri zaman dilimleri olarak tanımlanabilir. Kişilerin bu gibi stresli zaman dilimlerini açık alanlarda geçirmeleri yaşadıkları stres seviyelerini azaltıcı etki yapabilmektedir. Tüm bu ihtiyaçlar düşünüldüğünde ve hastaları ziyaret edecek kişi sayılarının değişimi de dikkate alındığında, açık alanlar tasarlanırken bireysel ve grup kullanımları dikkate alınarak, farklı grup büyüklüklerine hizmet edebilecek şekilde büyüklüğü değişebilen, esnek sınırları olan açık alanların yaratılması önemlidir. Bu süreçte düşünülmesi gereken bir diğer detay da hastaneye gelirken çocukları ile birlikte gelmek durumunda kalan ziyaretçilerdir. Ziyaret süresince çocukların güvende 
olmaları, kaliteli ve keyifli zaman geçirebilecekleri açık alan düzenlemelerinin varlığı kullanıcılar açısından olumlu bir detay olarak dikkat çekmektedir. Ayrıca çocukların varlığı, onlar için düzenlenmiş oyun alanlarının diğer kullanıcılar tarafından da izlenebilmesi hastane ortamının stresli ve gergin atmosferini azaltmada önemli bir tasarım detayıdır (Marcus ve Francis, 1997, s.312).

\section{Hastane Açık Alanları Tasarım Kriterleri}

Sağlık alanlarının fiziksel niteliklerinin tedavi sürecine olumlu yansımasındaki en etkili araçlarından bir tanesi bu mekânlarda bulunan açık alan düzenlemeleri olarak kabul edilebilir. İyi tasarlanmış hastane açık alanları; hastaları klinik ortamın oluşturduğu negatif etkilerden kurtararak, sosyal bir ortam oluşturmakta ve stresi azaltarak hastaların klinik sonuçlarını olumlu yönde etkilemektedir (Aksu ve Demirel, 2012, s.237; Desha, Walker, Reeve, 2016). Yapılan pek çok araştırmada; hastanelerde doğayla etkileşim halinde olmanın (aktif ve/veya pasif) stres, kolesterol, ağrı ve hastalık süresini azalttığına vurgu yapılmaktadır. Ayrıca hastane mekânlarında ve hastane yakın çevresinde doğal peyzaj elemanlarının kullanımının ve sunulan manzara olanaklarının tıbbi kontroller sırasında ağrı kontrolünde etkili bir yöntem olduğu, endişeyi azalttığı, cerrahi müdahalelerde rahatlama sağladığı, kan basıncını ve kalp atış hızını olumlu yönde etkilediği tespit edilmiştir (Karakaya ve Kiper, 2011, s.49; Epstein, 2013). Hastane açık alanları, yalnızca hastalar üzerindeki etkisi değil, aynı zamanda alanın diğer kullanıcılar (refakatçi, hekim, personel, öğrenci) üzerindeki etkileri de dikkate alınarak kurgulanmalıdır. Bu alanlar hekimler ve idari personel için yoğun çalışma saatleri arasında dinlenebilecekleri mekânlar olarak önem kazanmaktadır.

Sağlık birimleri açık alanlarının tasarımı, bulundurdukları işlevler açısından benzerlik gösterseler de mekânsal tasarım kararları açısından diğer kamusal mekânlara göre farklı nitelikteki yaklaşımları gerektirmektedir. Bu alanlarda bulunan kullanıcı profilinin dinamik ve sürekli değişen bir yapıda olması, alanın işlevsel özellikleri, alan içerisinde özel nitelikli mekanlar yaratma gerekliliğinin ve estetik kaygıların yanı sıra, doğal değerlerin rahatlatıcı ve dinlendirici etkilerinin de tasarım süreçlerine dahil edilmesini, peyzaj ögelerinin gerek fiziksel gerekse doğal niteliklerinin mekana entegrasyonunu desteklemektedir.

Sağlık alanlarının konfor nitelikleri ve iyileştirici özellikleri, kullanıc1ların yanı sıra doktorlar ve çalışan idari personel açısından da iş performansını arttırıcı nitelikleri ile dikkate alınmalıdır. Bu alanlarda kontrol ve 
güven hissinin yaratılması, fiziksel hareket ve egzersiz olanaklarının sunulması ve doğa ile etkileşim kurulabilecek ortamların oluşturularak dinlenme mekânlarının yaratılması öncelikli hedefler olarak belirlenmelidir. Ancak bu hedeflerin mekânsal olarak gerçekleştirilmiş olması işleyişte yeterli olmayabilir, bu alanların bilinmesi ve görsel olarak geçirgen olması, herkes için erişilebilir olması, aktif ve pasif kullanıma olanak vermesi, aydınlatılması, iklim etkilerinin (güneş, rüzgâr, yağmur vb.) dikkate alınarak tasarlanması ve ses yalıtımının sağlanması bu alanlar için tanımlanabilecek diğer önemli nitelikler olarak siralanabilirler (Tablo 1) (Severtsen, 2006, s.3).

Tablo 1. Hastane açık alanları tasarım kriterleri uygulama örnekleri

Fiziksel hareket olanakları

Kullanıcılara sağlık alanı yakın çevresinde, doğa ile bütünleşmiş, stres bileşenlerinin azaltıldığ 1 , fiziksel hareket imkânı verecek dolaşım güzergâhları yaratılması önemlidir.

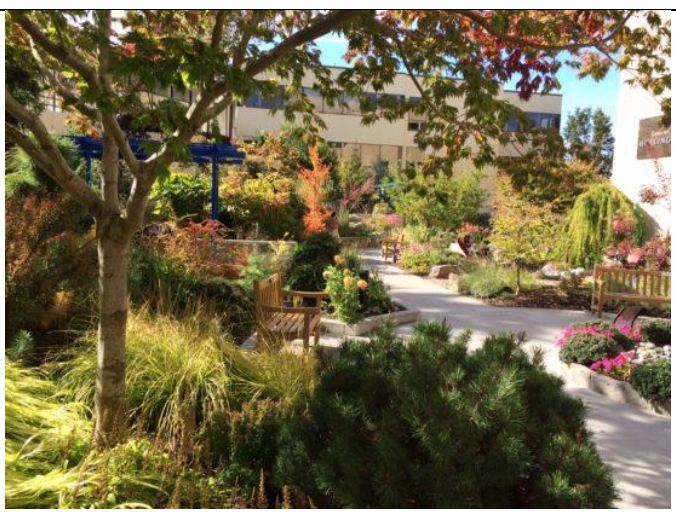

(Kaynak: Sachs, 2016)

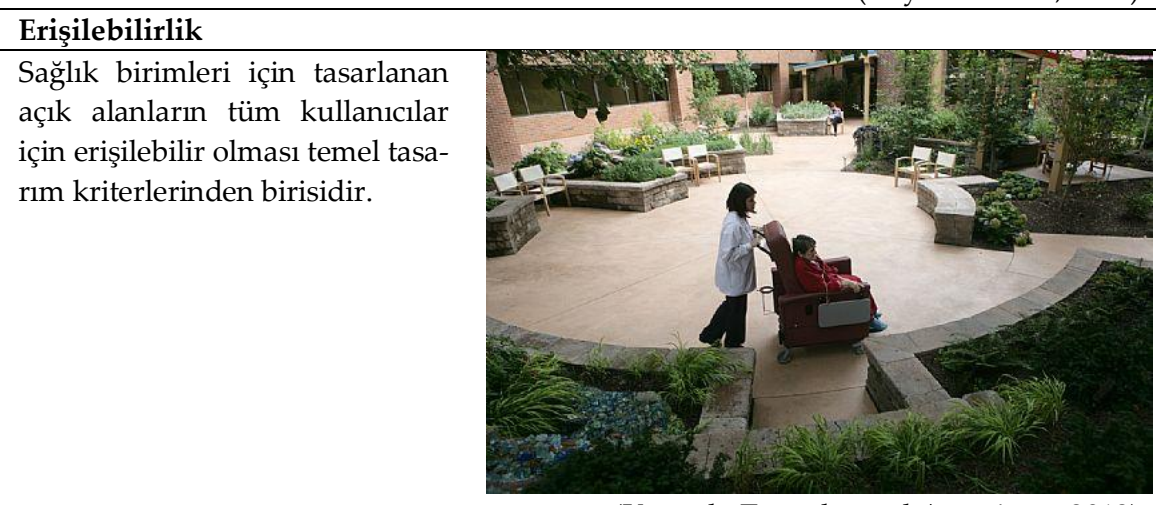

(Kaynak: Zaretsky and Associates, 2018) 


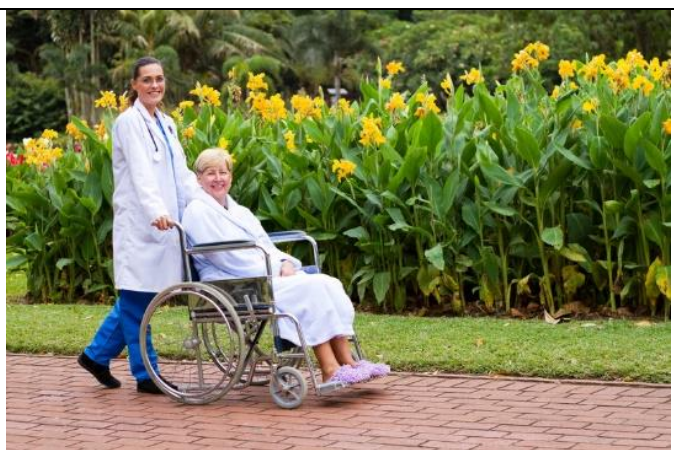

(Kaynak: LMC Embark, 2016)

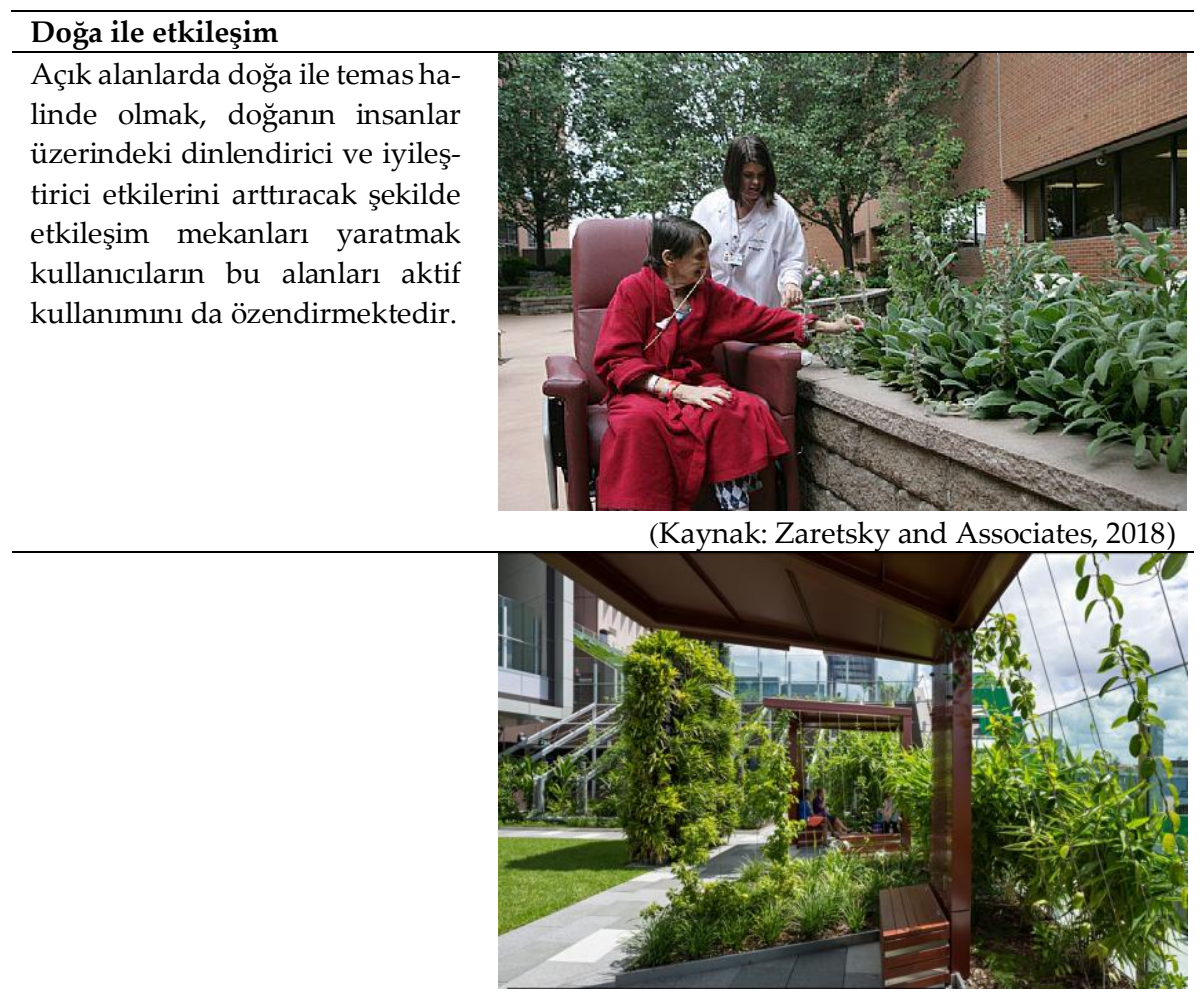

(Kaynak: Desha, Walker, Reeve, Jones, 2016) 


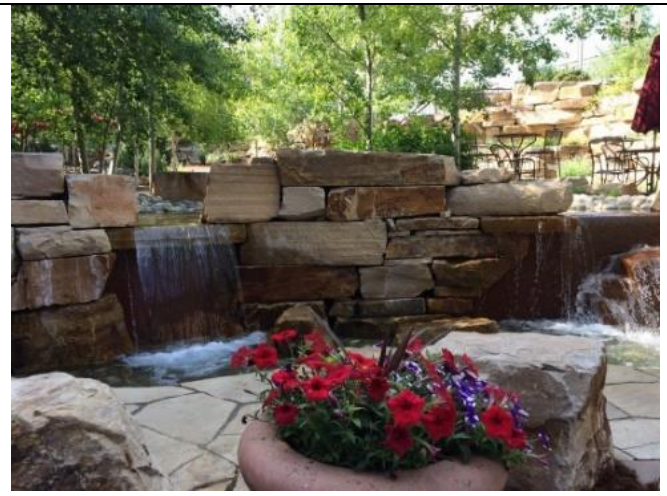

(Kaynak: Spillmann, 2017)

\section{Görsel geçirgenlik}

Tasarlanan açı ve yeşil alanların görsel olarak geçirgen olması; hem açık alanlarda bulunan kullanıcılara güvenlik hissi yaratmada, hem de bina içerisindeki kullanıcılara doğa ile temas kurmada yardımcı olmaktadır.

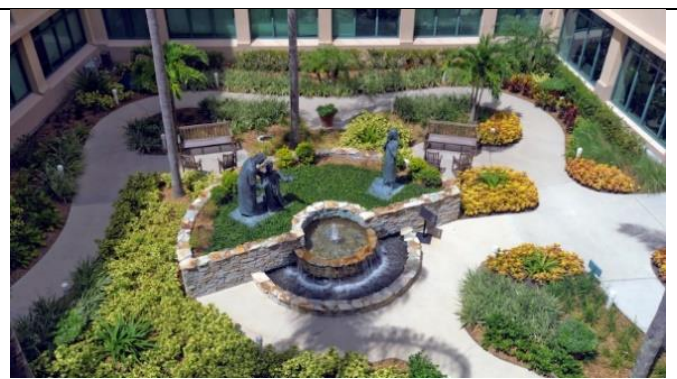

(Kaynak: Milano Citta Stato, 2016)

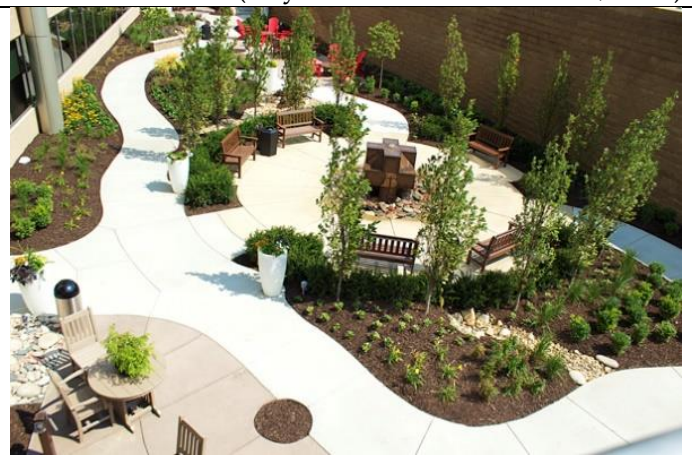

(Kaynak: Placzek, 2013)

\begin{tabular}{l} 
Aktif ve pasif kullanım olanakları \\
Açık ve yeşil alanların hem ak- \\
tif hem de pasif kullanıma ola- \\
nak verecek şekilde tasarlan- \\
ması, gerek bireysel kullanım \\
açısından, gerekse gruplar ha- \\
linde bu alanlara gelen kulla- \\
nıcılar açısından rahatlıkla za- \\
man geçirilebilecek mekânlar \\
yaratmaktadır. \\
\hline
\end{tabular}




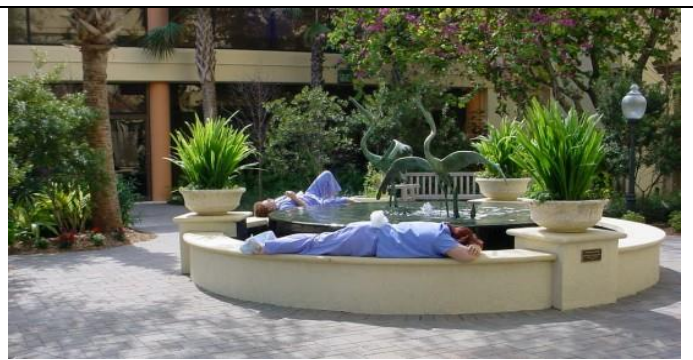

(Kaynak: Sachs, 2016)

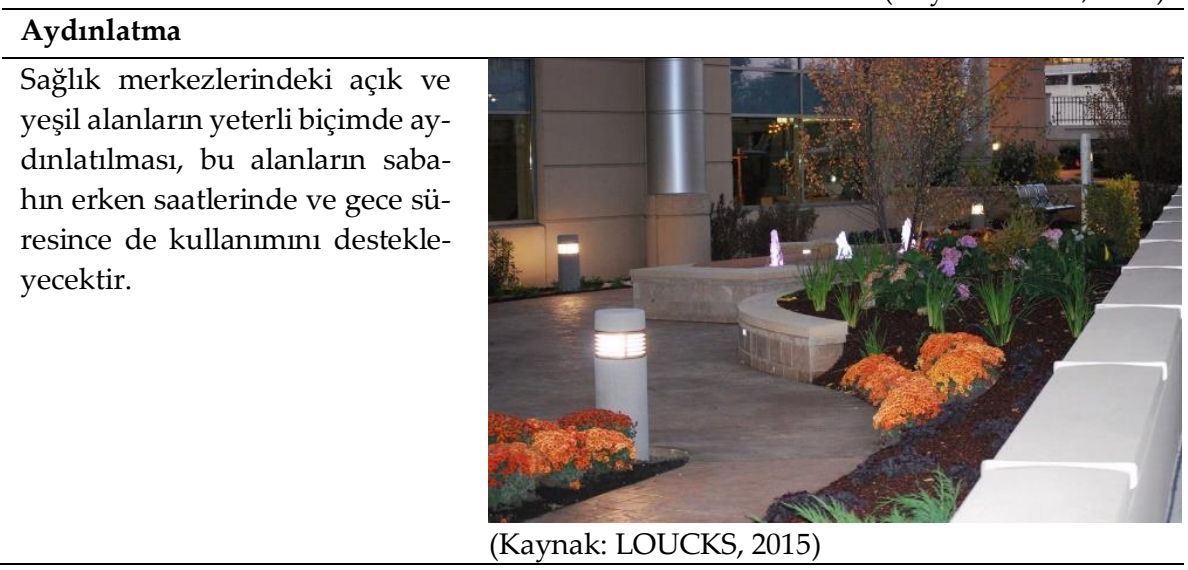

\begin{tabular}{l} 
İklim etkilerine (güneş, rüzgâr, yağmur vb.) uyumlu tasarım \\
\hline Sağlık birimleri kapsamında ele \\
alınan açk ve yeşil alan tasarımla- \\
rında iklim koşullarına uyumlu ta- \\
sarım detaylarının düşünülmesi, \\
düzenlenen açı alanların daha \\
uzun süreli ve konforlu kullanı- \\
mını sağlamaktadır. \\
\hline Ses yalıtımı \\
\hline
\end{tabular}


Hastane açık alanlarında ses yalıtımının sağlanabilmesi için bu alanlar; genelde iç avlularda ya da arka cephelerde, yoğun sirkülasyon alanlarından uzak olacak şekilde konumlandırılmaktadır.

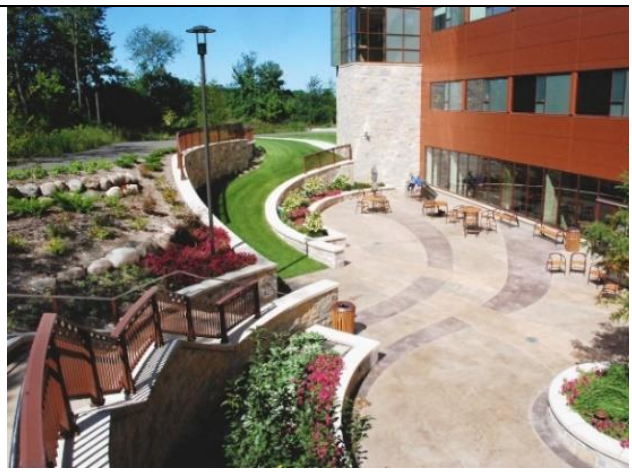

(Kaynak: LOUCKS, 2006)

\section{Hastane Kullanıcılarının Açık Alan İhtiyaçlarının Belirlenmesi ve Açık Alan Tasarım İlkeleri, Ankara Gazi Üniversitesi Hastanesi Ör- neği}

Hastanelerin kent ile bütünleşmesini sağlayan temel kurgu işlevsel ve mekânsal ilişkiler olmak üzere iki başlık altında ele alınabilir. İşlevsel konular hastane yönetiminin işletmeye ait stratejileri ile ilişkilidir, hastane alanlarının hangilerinin kamu kullanımına açılacağı, sağlık hizmetlerini destekleyen ticari ve rekreasyonel faaliyetlerin (farklı türdeki restoranların bulunması, kentliler için rekreasyon alanlarının ve sağlık amaçlı spor programlarının sunumu vb.) nasıl organize edileceği gibi konular doğrudan, hizmet sunan sağlık biriminin işletme kararlarına bağlıdır. Bu eylemler hastane mekânlarında canlılığı sağlayacağı gibi kent ile bütünleşmede önemli yardımcı araçlardır (Setola ve Borgianni, 2016, s.13).

Mekânsal niteliklerle ilişkili olan ikinci konu ise hastane mekânlarının ve ulaşım akslarının kentsel ağ ile fiziksel bütünleşmesini kapsamakta, hastane dış mekânlarının, ara bağlantı mekânlarının ve hastane iç dolaşım sistemlerinin (koridorlar, merdivenler, asansörler vb.) tüm dolaşım ağına entegrasyonunu konu edinmektedir. Farklı kamusal mekânların fiziksel sürekliliği, sağlık odaklı çevrelere daha fazla erişilebilirliği sağlamakta ve hastane alanları içerisinde bulunan aktif kamu kullanımını desteklemektedir. Bu bütünleşmenin sağlanmasında "geçiş mekânları" (interface spaces)nın tasarımı günümüz kentlerinin temel tasarım konularından birisidir (Setola ve Borgianni, 2016, s.23, 38).

Ankara Gazi Üniversitesi Hastanesi, yeni adıyla Gazi Üniversitesi Sağlık Araştırma ve Uygulama Merkezi, bünyesindeki akademik personel, 
doktor sayısı ve niteliği açılarından Türkiye'nin önde gelen sayılı Tıp Fakültelerinden birisidir. Kent içindeki konumu ve sunduğu nitelikli hizmet ile gerek Ankara gerekse Türkiye' nin tüm illerinden hasta kabul eden bir tıp fakültesi olarak hizmet vermektedir. Hastane, Ankara kent merkezinin batısında, kentsel kullanımlarla (ulaşım güzergâhları, kent parkları, konut alanları, kamusal hizmet alanları, alışveriş merkezleri vb.) yakın ve erişilebilir mesafeler içinde yer almaktadır. Bu durum hastanenin kentle kurduğu ilişkiyi güçlendirmektedir. Kentin yoğun yerleşim bölgelerinden olan Gazi Mahallesi, Beşevler Mahallesi, Bahçelievler Mahallesi ve Emek Mahallesi'ne yakın olması, yakın çevresindeki eğitim alanları ile mekânsal ilişkisi ve bu konumu sebebiyle de toplu taşıma hatlarına yakınlığı dikkat çekmektedir. Ayrıca kentin ana ulaşım arterlerinden Konya-Samsun karayolu (Mevlana Bulvarı) üzerinde bulunması da hastanenin erişilebilirliğini kolaylaştırmakta, kent merkezi, kentsel yerleşim alanları ve kent çeperlerindeki yaşam alanları ile kurulan güçlü bağlantı hastaneyi kamusal bir odak haline getirmektedir (Şekil 1).

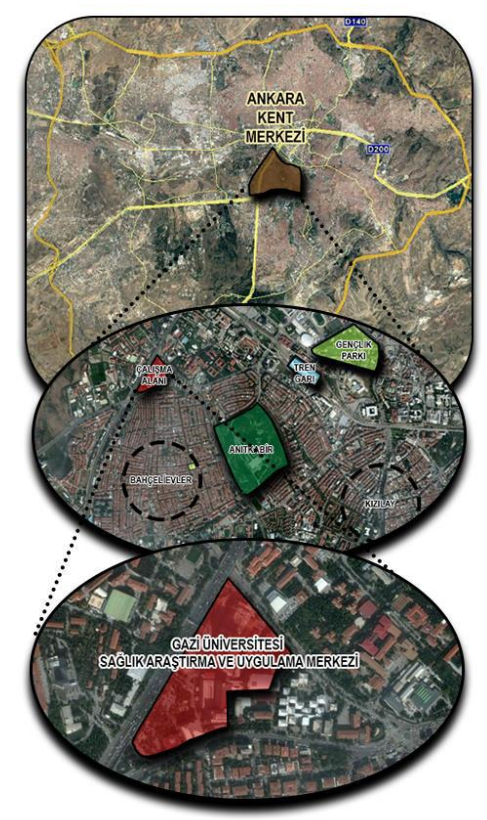

Şekil 1. Gazi Üniversitesi Sağlık Araştırma ve Uygulama Merkezi'nin Kentsel Konumu

Gazi Üniversitesi Sağlık Araştırma ve Uygulama Merkezi Yenileme Çalışmaları 
Gazi Üniversitesi Tıp Fakültesi 1979'da Ankara İktisadi ve Ticari İlimler Akademisi'ne bağlı bir Tıp Fakültesi olarak “Dr.Muhittin Ülker Acil Yardım ve Travmatoloji Hastanesi" adı ile kurulmuş, zamanla yaşadığı değişim ve dönüşüm ile 1984 yılında bugünkü, modern Gazi Hastanesi'nin temeli atılmıştır. 1985 yılında Gazi Üniversitesi Tıp Fakültesi olarak ilk mezunlarını veren hastane Beşevler bölgesinde 1986 yılında ihtiyaç duyulan yeni binaların yapılması ile mekânsal olarak da gelişmeye başlamıştır. 1994 yılında poliklinik binası, 1997 yılında yataklı üniteler, laboratuvar ve tıbbi görüntüleme ünitelerinin olduğu bölümler hizmete girmiş, acil servis ve ek hastane blokları 2000 tarihinde açlmış, böylece hastane kompleksi bugünkü mevcut durumuna gelmiştir. Güncel adı "Gazi Üniversitesi Sağlık Araştırma ve Uygulama Merkezi" olan hastane, gerek verdiği sağlık hizmetleri gerekse eğitim hizmetleri sebebi ile farklı mekânsal düzenlemelerin biraradalığını gerektirmiş, eğitim alanlarının ve hastane kapasitesinin yıllar içerisinde artan talebi karşılayamaması nedeniyle merkez alanı içerisinde yenileme çalışmalarına ihtiyaç duyulmuştur. 2014 yilında yetersizliklerin giderilebilmesi ve yeni ek hizmetlerin sunulabilmesi amacı ile hastane kampüs alanında 12 katlı bir ek binanın yapımına başlanmış, kullanım ömürlerini tamamlamış binaların y1kılması ile elde edilecek alanların da hastane kompleksi bütününde ihtiyaçları karşılayacak şekilde işlevlendirilmesi kararı alınmıştır (Şekil 2) (Gazi Hastanesi Web Sitesi, 2017).

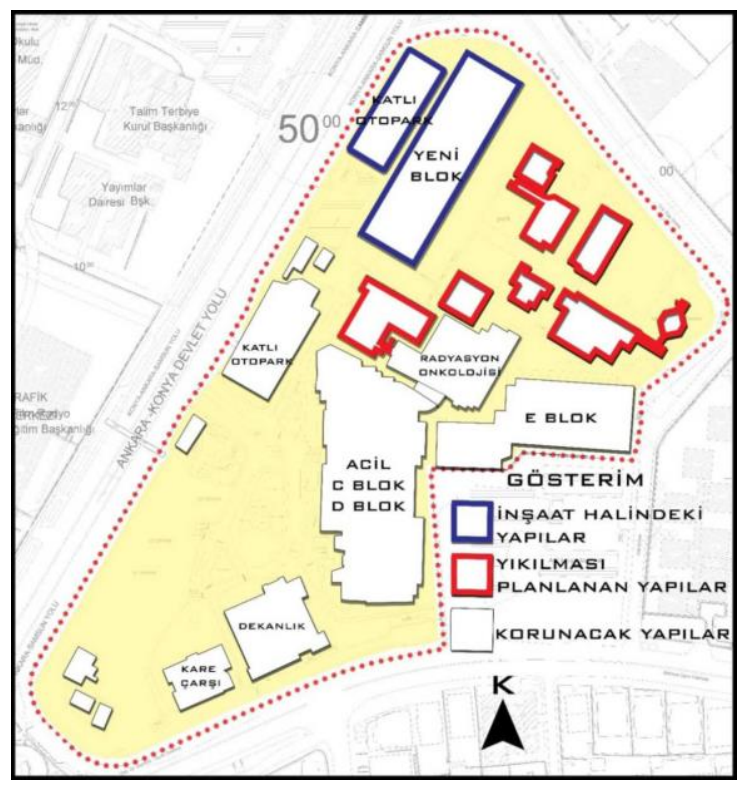

Şekil 2. Hastane Kampüs Alanında Yapılar ve Mevcut Durumları 
Yenileme çalışmaları kapsamında alanda yıkılacak eski yapıların olması alanın kent ile bütünleşmesinde, herkes tarafından kullanılabilecek açık kamusal mekânların yaratılmasını sağlayarak avantajlı bir duruma dönüştürülebilir. Buna karşın yapılmakta olan yeni yapının yüksek katlı olması ve mevcut kullanım kapasitesini de arttıracak olması, hastanenin kullanıcı sayısında ve personel sayısında da artışa sebep olacak ihtiyaç duyulan işlev alanlarının (otopark alanları, kişi başı ihtiyaç duyulan açık alan büyüklükleri, restoran, büfe alanları vb.) sayıları ve büyüklükleri de bununla ilişkili olarak artacaktır. Bu süreçte kamusal açık alanların kullanıcı ihtiyaçlarını en etkin biçimde karşılayabilmesine ve eşzamanlı kent ile bütünleşmeyi sağlayacak şekilde düzenlenmesine özen gösterilmeli, açık alanların, işlevsel bütünlük de dikkate alınarak tasarlanması esas alınmalıdır.

\section{Bulgular}

Çalışmada öncelikle Gazi Üniversitesi Sağlık Araştırma ve Uygulama Merkezi kullanıcılarının açık alan kullanım durumları ve açık alan ihtiyaçları / beklentileri belirlenmeye çalışılmış, bunun için farklı kullanıcı grupları ile görüşmeler ve katılmak isteyen katılımcılar ile anket çalışması gerçekleştirilmiştir. Daha sonra belirlenen istek ve ihtiyaçların karşılanmasında mevcut düzenlemelerin yeterli olup olmadığının, yeterli olmadığı durumlarda ise hangi konularda eksikliklerin olduğunun tespit edilebilmesi ve çözüm önerileri geliştirilebilmesi amacıyla arazi çalışmaları ile analizler yapılmıştır.

Anket çalışması kullanıcı çeşitliliğinin ortaya konması, farklı kullanıcıların alan kullanım alışkanlıklarının ve kullanım amaçlarının belirlenmesi, farklı kullanıcı gruplarının farklılaşan ihtiyaçlarının ortaya konulması amacryla gerçekleştirilmiş, değerlendirmeler de gruplar özelinde yapılmıştır. Hastane kullanıcıları; "hastalar, refakatçi ve ziyaretçiler, hastane personeli ve öğrenciler" olmak üzere dört farklı grupta ele alınmıştır. Her bir kullanıcı grubu ile, 10-15 Aralık 2016 tarihleri arasında, farklı saatlerde, bulunulan ortamın stresi, psikolojik etkileri, zaman kısıtlılığ1 ve yoğunluğu da dikkate alınarak, sınırlı sayıda anket yapılmış, rastgele örneklem yöntemi kullanılmış ve katılımda gönüllülük esas alınmıştır. Grupların her birine 30 anket olmak üzere toplamda 120 anket uygulanmış, elde edilen sonuçlar frekans dağılımları ve çapraz sorgulamalar ile analiz edilmiştir. 
Anket katılımcıları belirlenirken her grup için dengeli bir dağılım sağlanmaya çalışılmış, kadın erkek oranlarının eşit olmasına dikkat edilerek, her grup için kadın erkek dağılımı \%50 olarak belirlenmiştir. Ancak ziyaretçi anketlerinde bu oran (katılımcıların gönüllülükleri esas alındığından) \% 73 kadın -\% 27 erkek olarak değişmiştir. Anket değerlendirmeleri yapılırken her grup için öncelikle kullanıcıların yaş dağılımları verilmiş, ardından farklı kullanıcı gruplarının merkezin açık alanlarını mevcut kullanım şekli, sağlık birimlerinin açık alanlarından beklentileri ve Gazi Üniversitesi Sağlık Araştırma ve Uygulama Merkezi açık alanlarından memnuniyet durumları sorgulanmaya çalışılmıştır.

\section{Hasta Anketlerinin Değerlendirilmesi}

Gazi Üniversitesi Sağlık Araştırma ve Uygulama Merkezi'nde bulunan ve ankete katılan hastaların yaş dağılımına bakıldığında en yoğun aralığın 20-50 yaş grubu (\%63) olduğu görülmektedir. Bunu \%17 oranları ile 12-20 yaş grubu ve 51 yaş ve üzeri kişiler takip etmektedir. Kalan \%3'lük kesim ise 7-12 yaş grubundan oluşturmaktadır (Şekil 3).

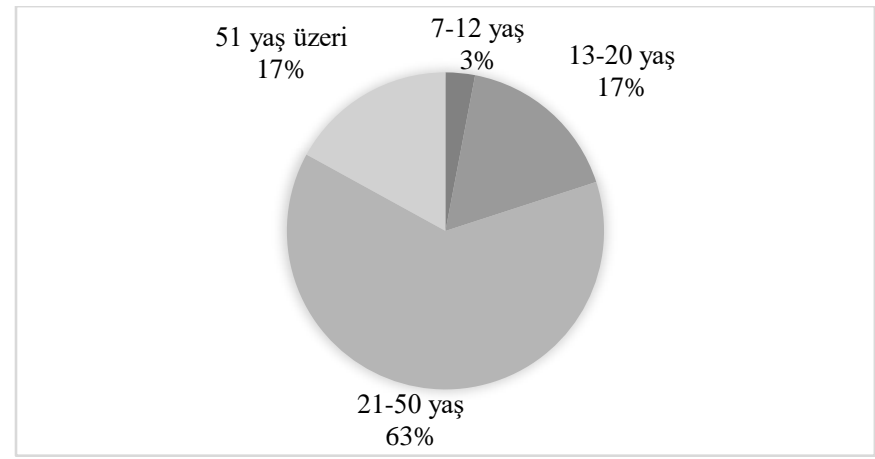

Şekil 3. Hastaların Yaş Dağılımı

Gazi Hastanesi'nde bulunan ve ankete katılan hastaların yarısından fazlasın $(\% 53)$ merkezi yalnızca acil durumlarda ya da anlık hastalık durumlarında kullanan hastalar oluşturmaktadır. Bunu \%27 ile hastalık tedavisi amaciyla sürekli gelen hastalar ve \%20 ile sadece düzenli kontrol için gelen hastalar takip etmektedir (Şekil 4). 


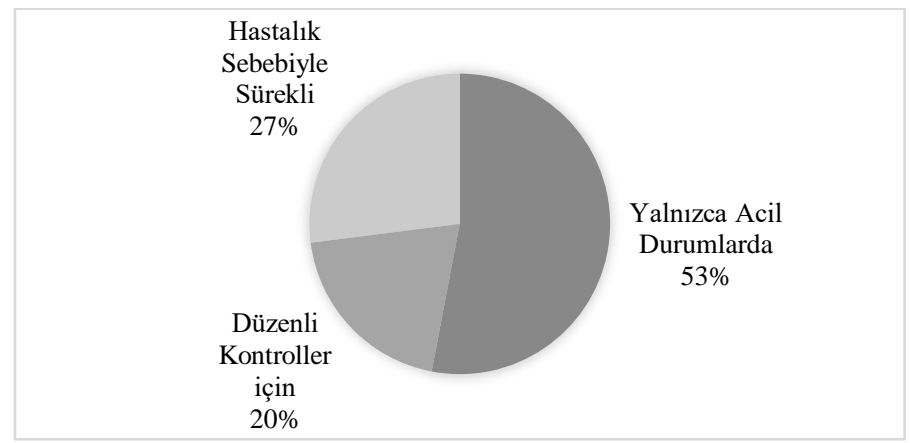

Şekil 4. Hastaların Merkezi Ziyaret Sıklı̆̆ı

Anket yapılan hastalara geldiklerinde hastanede kalış süreleri sorulmuş, \%60 oranında kısa süreli olarak (0-1 gün) hastanede kalındığ tespit edilmiştir. Hastanede 1-7 gün kalan hastaların oranı \%27, bir haftadan daha uzun süreli hastanede kalan hastaların oranı ise \%13'tür (Şekil 5).

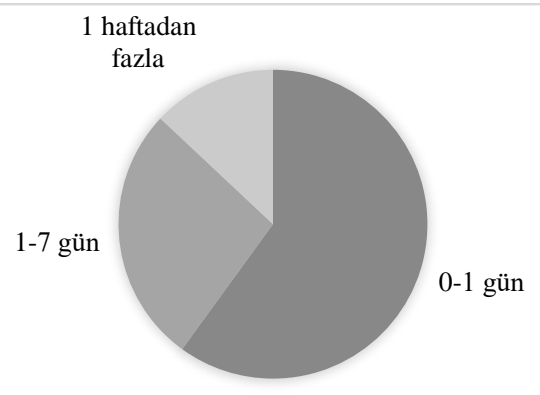

Şekil 5. Hastaların Merkezde Kalış Süreleri

Gazi Üniversitesi Sağlık Araştırma ve Uygulama Merkezi'ndeki hastaların merkeze geliş sıklıkları ve merkezi kullanım süreleri analiz edildikten sonra, bu veriler hastaların merkezin açık alanlarını kullanım biçimleri, bu durumdan memnuniyetleri ve açık alanlardan beklentileri ile çapraz sorgulanarak analiz edilmiştir. Yapılan ilk analizde; hastaların merkeze geliş sıklıkları ve açık alanları kullanım biçimleri arasındaki ilişki değerlendirilmiş, açık alanları; acil durumlarda gelen hastaların daha çok geçiş amaçlı kullandıkları, düzenli kontrole gelen hastaların otopark amaçlı kullandıkları buna karşın hastalığı sebebi ile sürekli tedaviye gelen hastaların açık alanlarda daha çok vakit geçirerek yeme içme alanlarını kullandıkları belirlenmiştir (Tablo 2). 
Tablo 2. Hastaların merkeze geliş sıklıkları ve açık alanları kullanım biçimi ilişkisi

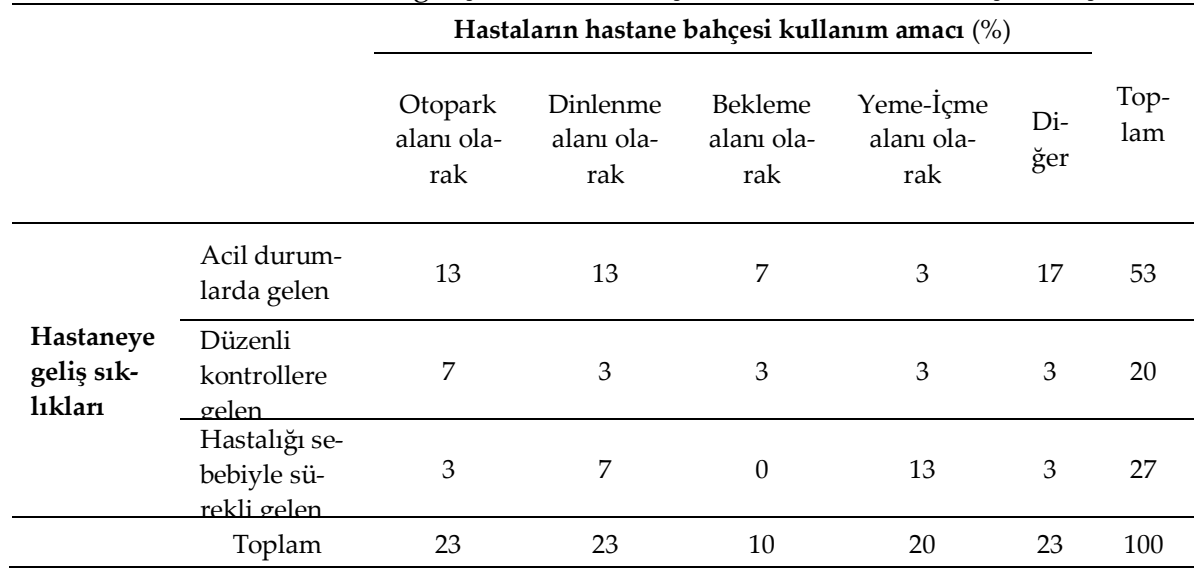

Hastaların kalış süreleri ile açık alan kullanım ilişkisi incelendiğinde, açık alanları kullanım amaçlarının kalış sürelerine göre farklılaştığı görülmektedir. Hastaneye kısa süreli gelen hastalar için açık alanlar açısından otopark ağırlıklı bir kullanım biçimi (\%44) söz konusuyken, uzun süreli kalan hastalar için daha çok yeme içme aktivitelerinin yapıldığ \%75) olarak öne çıkmaktadır (Tablo 3).

Tablo 3. Hastaların merkezde kalış süresi ve açık alanları kullanım biçimi ilişkisi

Hastaların hastane bahçesi kullanım amacı (\%)

\begin{tabular}{llcccc}
\cline { 2 - 6 } & $\begin{array}{c}\text { Otopark } \\
\text { Alanı Ola- } \\
\text { rak }\end{array}$ & $\begin{array}{c}\text { Dinlenme } \\
\text { Alanı Ola- } \\
\text { rak }\end{array}$ & $\begin{array}{c}\text { Bekleme } \\
\text { Alanı Ola- } \\
\text { rak }\end{array}$ & $\begin{array}{c}\text { Yeme İçme } \\
\text { Alanı Ola- } \\
\text { rak }\end{array}$ \\
\hline \multirow{3}{*}{$\begin{array}{l}\text { Hastanede kalış } \\
\text { süresi }\end{array}$} & $0-1$ Gün & 44 & 28 & 28 & 0 \\
\cline { 2 - 6 } & $1-7$ Gün & 13 & 25 & 13 & 50 \\
\cline { 2 - 6 } & +7 Gün & 0 & 25 & 0 & 75 \\
\hline
\end{tabular}

Açık alan kullanım tercihleri sorulduğunda acil/anlık rahatsızlıklar sebebi ile gelen hastaların açık alanları daha çok bekleme ve dinlenme amaçlı kullanmak istedikleri, düzenli kontrollere gelen hastaların ise yeme içme amaçlı kullanmayı tercih edecekleri görülmektedir (Tablo 4). 
Tablo 4. Hastaların merkeze geliş sıklıkları ve açık alanları hangi amaçla kullanmak istedikleri

\begin{tabular}{lcccccc}
\hline & $\begin{array}{c}\text { Otopark } \\
\text { alanı olarak }\end{array}$ & $\begin{array}{c}\text { Dinlenme } \\
\text { alanı olarak }\end{array}$ & $\begin{array}{c}\text { Bekleme alani } \\
\text { olarak }\end{array}$ & $\begin{array}{c}\text { Yeme-içme } \\
\text { alanı olarak }\end{array}$ & Diğer & Toplam \\
\hline $\begin{array}{l}\text { Acil durum- } \\
\text { larda gelen }\end{array}$ & 10 & 23 & 17 & 0 & 3 & 53 \\
\hline $\begin{array}{l}\text { Düzenli kont- } \\
\text { rollere gelen }\end{array}$ & 0 & 7 & 0 & 10 & 3 & 20 \\
\hline $\begin{array}{l}\text { Hastalığı sebe- } \\
\text { biyle sürekli ge- } \\
\text { len }\end{array}$ & 0 & 13 & 10 & 3 & 0 & 27 \\
\hline Toplam & 10 & 43 & 27 & 13 & 7 & 100 \\
\hline
\end{tabular}

Hastaların mevcuttaki kullanım biçimlerinden bağımsız olarak hastane açık alanlarını ne amaçla kullanmayı istedikleri hastanede kalış süreleri ile ilişkilendirildiğinde; kalış süreleri farklı da olsa, tüm kullanıcılar açısından dinlenme amaçlı kullanım biçimi ilk sıraya yerleşmektedir (Tablo 5).

Tablo 5. Hastaların merkezde kalış süresi ve açık alanları hangi amaçla kullanmak istedikleri

\begin{tabular}{lccccc}
\hline & & \multicolumn{3}{c}{ Hastaların hastane bahçesini hangi amaçla kullanmak istedikleri (\%) } \\
\cline { 2 - 6 } & & $\begin{array}{c}\text { Otopark Alanı } \\
\text { Olarak }\end{array}$ & $\begin{array}{c}\text { Dinlenme } \\
\text { Alanı Olarak }\end{array}$ & $\begin{array}{c}\text { Bekleme Alanı } \\
\text { Olarak }\end{array}$ & $\begin{array}{c}\text { Yeme içme Alanı } \\
\text { Olarak }\end{array}$ \\
\hline \multirow{2}{*}{$\begin{array}{l}\text { Hasta- } \\
\text { nede ka- } \\
\text { liş süresi }\end{array}$} & 0-1 Gün & 6 & 56 & 28 & 11 \\
\cline { 2 - 6 } & 1-7 Gün & 13 & 38 & 25 & 25 \\
\hline +7 Gün & 25 & 50 & 25 & 0 \\
\hline
\end{tabular}

Hastaların hastanede kalış süreleri ve bu sürede açık alanları kullandıkları günlük zaman dilimleri sorgulanmış, hastanede kalış süresi değişse bile, en yoğun kullanılan zaman aralığının 10.00-14.00 saatleri arası olduğu görülmüştür. Bu durum, hastaların sabah doktorları gördükten ya da temel tedavi işlemlerini tamamladıktan sonra ya da öğle tatili sonrasındaki randevuları beklerken bu alanları daha yoğun kullandıkları şeklinde yorumlanabilir. Uzun süreli hastanede kalan hastalar için ise yeme-içme aktiviteleri ve dinlenme amaçlı kullanımlar göz önüne alındığında öğle saatlerinin yoğun kullanılıyor olması beklenen bir durumdur (Tablo 6). 
Tablo 6. Hastaların merkezde kalış süreleri ve açık alanları kullandıkları zaman aralığ 1 ilişkisi

\begin{tabular}{lccccc}
\hline & \multicolumn{4}{c}{ Hastane bahçesini kullanım zamanlarına göre hasta sayıları (\%) } \\
\cline { 2 - 6 } & $\begin{array}{c}\text { 06.00-10.00 } \\
\text { Arası }\end{array}$ & $\begin{array}{c}10.00-14.00 \\
\text { Aras }\end{array}$ & $\begin{array}{c}14.00-18.00 \\
\text { Arası }\end{array}$ & $\begin{array}{c}\text { 18.00-22.00 } \\
\text { Aras }\end{array}$ \\
\hline \multirow{2}{*}{$\begin{array}{l}\text { Hasta- } \\
\text { nede ka- } \\
\text { lı̧ süresi }\end{array}$} & $0-1$ Gün & 11 & 77 & 6 & 6 \\
\cline { 2 - 6 } & 1-7 Gün & 12 & 38 & 25 & 25 \\
\hline
\end{tabular}

Katılımc hastaların merkezin açık alanlarından memnuniyeti sorulduğunda ise merkezde kalış süresi artmasıyla açık alanlardan memnuniyetin azaldığı söylenebilir (Tablo 7). Açık alanları en çok kullanan kullanıcıların en uzun süre kalan hastalar olduğu göz önüne alındığında memnuniyetsizlik durumunun onlar tarafından üst düzeyde bulunması önemli bir göstergedir.

Tablo 7. Hastaların merkezde kalış süresi ve merkezin açık alanlarından memnuniyeti arasındaki ilişki

Gazi Üniversitesi Sağlık Araştırma ve Uygulama Merkezi açık alanlarindan memnuniyet (\%)

\begin{tabular}{lcccc}
\cline { 2 - 5 } & & $\begin{array}{c}\text { Evet, Memnunum } \\
\text { Yeterli Geliyor }\end{array}$ & $\begin{array}{c}\text { Evet, Memnunum } \\
\text { Ancak Geliştirilebilir }\end{array}$ & $\begin{array}{c}\text { Hayır, } \\
\text { Memnun Değilim }\end{array}$ \\
\hline \multirow{3}{*}{$\begin{array}{l}\text { Hastanede } \\
\text { kalış süresi }\end{array}$} & 1-1 Gün & 28 & 28 & 44 \\
\cline { 2 - 5 } & +7 Gün & 38 & 38 & 25 \\
\hline
\end{tabular}

Katılımcı hastalardan, merkezin açık alanlarından memnun olmayan ve merkezin açık alanlarının geliştirilebilir olduğunu düşünen katılımcılara memnuniyetsizlik yaratan sebepler ve bunlara çözüm önerileri sorulmuş, hangi konularda düzenlemelerin yapılmasının onları mutlu edeceği tespit edilmeye çalışılmıştır. Hastalar tarafından dile getirilen, çözülmesi gereken ilk konu; alan içerisindeki taşıt ve yaya hareketliliğinin bir arada olmasından kaynaklanan karmaşadır. Bu temel problemi yeşil alanların azlığı ve düzenlenmiş oturma mekânlarının yetersizliği takip etmektedir (Şekil 6). 


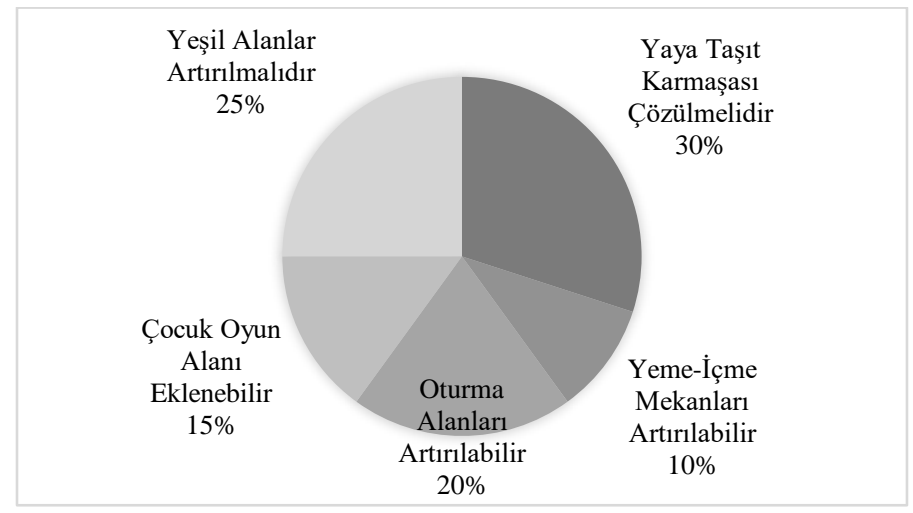

Şekil 6. Hastaların Hastanenin Açık Alanlarından Beklentileri

\section{Refakatçi ve Ziyaretçi Anketlerinin Değerlendirilmesi}

Hastanelerin kullanıcı gruplan arasındaki önemli gruplardan bir tanesi de hastaların ziyaretçi ve refakatçileridir. Gerek hastalara moral vermeleri, normal yaşamın devam ettiğini hissettirmeleri, gerekse onlara hastane süreçlerinde yardımcı olmaları açısından bu kullanıcı grubu (özellikle de refakatçiler) hastanelerin aktif açık alan kullanıcıları arasındadır. Hatta bazı durumlarda açık alanları hastalardan daha çok refakatçilerin kullandığını söylemek de mümkündür. Bu nedenle açık alan düzenlemelerine ilişkin memnuniyetin sorgulanmasında bu kullanıcı grubunun görüşleri önemlidir.

\section{Refakatçi Anketlerinin Değerlendirilmesi}

Gazi Üniversitesi Sağlık Araştırma ve Uygulama Merkezi'nde bulunan ve ankete katılan refakatçilerin \%43'ü ilk defa bir hastaya refakat ettiklerini belirtmişlerdir. Katılımcıların \%37'si daha önce de refakatçi olarak bir hastaya eşlik ettiklerini, \%20'si ise sık sık hasta refakatçisi olarak hastanede bulunduklarını söylemişlerdir (Şekil 7).

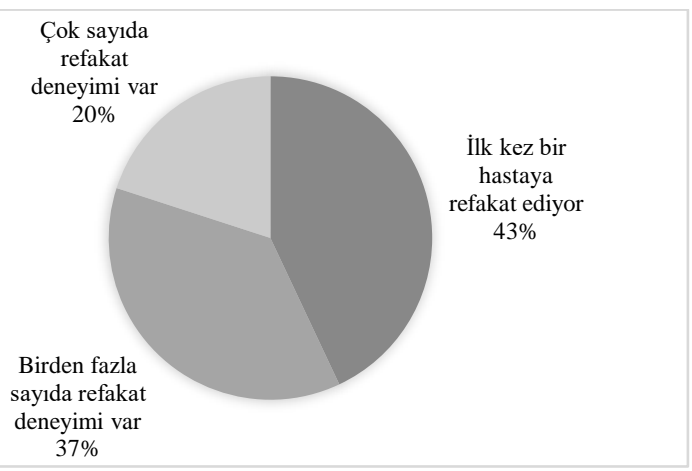

Şekil 7. Hasta Refakatçilerinin Refakat Deneyimleri 
Anket yapılan refakatçilerin refakat sürelerine bakıldığında kısa süreli (012 saat aras1) refakatlerin \%33'le en fazla olduğu, bunu \%27'lik oran ile en fazla 1 gün süreli refakatlerin izlediği, 1 günden fazla süreli refakatçi sayılarının ise eşit oranlı dağıldığı görülmektedir (Şekil 8).

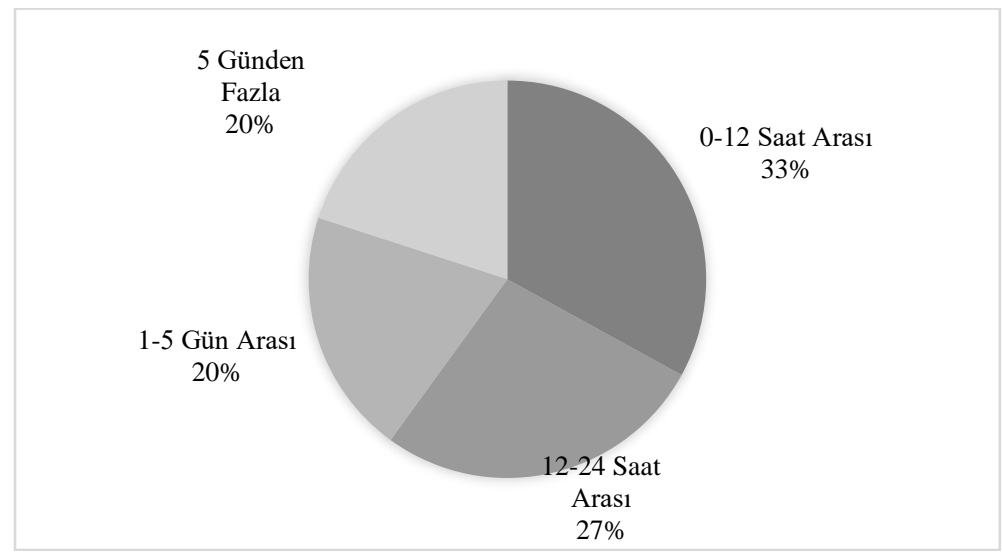

Şekil 8. Refakatçilerin Refakat Süreleri

Anket yapılan refakatçilerin refakat tecrübeleri ve refakat süreleri analiz edildikten sonra, merkezi kullanım sürelerine göre, refakatçilere merkezin açık alanlarından memnuniyet durumlarını ve beklentilerini belirlemeye yönelik sorular yöneltilmiştir. Katılımcı refakatçiler Tablo 8' de görüldüğü üzere merkezin açık alanlarını otopark alanı ve bekleme alanı olarak kullanmaktadırlar. Bu kullanıcılara beklentileri sorulduğunda ise tıpkı hastalar gibi daha çok dinlenme ve yeme içme alanı olarak kullanmayı tercih edeceklerini belirtmişlerdir (Tablo 9).

Tablo 8. Refakatçilerin refakat süresi ile açık alanları kullanım amaçları arasındaki ilişki

\begin{tabular}{llcccc}
\hline & & \multicolumn{2}{c}{ Kalınan süre boyunca hastane bahçesinin kullanım amacı (\%) } \\
\cline { 2 - 6 } & \multicolumn{1}{c}{$\begin{array}{c}\text { Otopark } \\
\text { Alanı Olarak }\end{array}$} & $\begin{array}{c}\text { Dinlenme Alanı } \\
\text { Olarak }\end{array}$ & $\begin{array}{c}\text { Bekleme } \\
\text { Alanı Olarak }\end{array}$ & $\begin{array}{c}\text { Yeme İçme } \\
\text { Alanı Olarak }\end{array}$ \\
\hline \multirow{2}{*}{$\begin{array}{l}\text { Refa- } \\
\text { kat } \\
\text { süresi }\end{array}$} & $\begin{array}{l}\text { 12-24 Saat } \\
\text { Arası }\end{array}$ & 60 & 20 & 20 & 0 \\
\cline { 2 - 6 } & 1-5 Gün Arası & 0 & 13 & 38 & 0 \\
\cline { 2 - 6 } & $\begin{array}{l}\text { 5 Günden } \\
\text { Fazla }\end{array}$ & 0 & 33 & 67 & 0 \\
\hline
\end{tabular}


Tablo 9. Refakatçilerin refakat süresi ve açık alanları kullanmak istediği amaç ilişki

Kalınan süre boyunca hastane bahçesinin kullanım amacı isteği(\%)

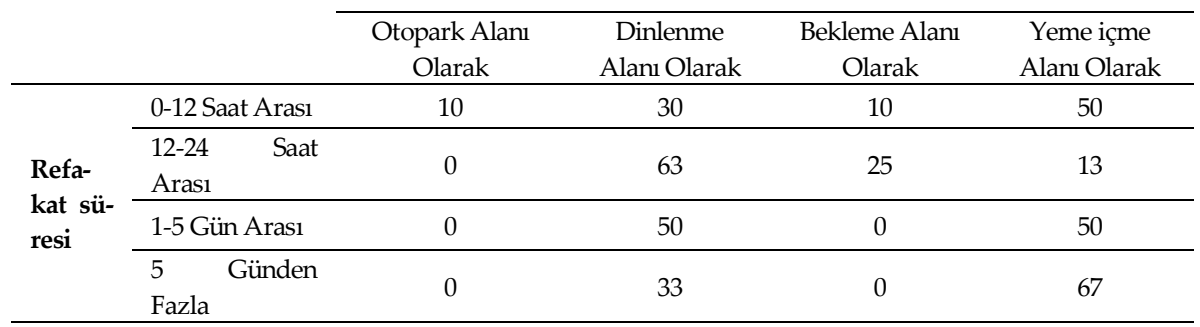

Refakatçilerin refakat süresi arttıkça merkezin açık alanlarını 10.00 -14.00 saatleri arası kullanımlarının azaldığı görülmektedir. Diğer zaman dilimlerindeki kullanım yoğunluklarının ise refakat süresinden bağımsız olarak değiştiği, 14.00-18.00 saatleri arasında açık alan kullanımının daha çok tercih edildiği görülmektedir (Tablo 10).

Tablo 10. Refakatçilerin refakat süreleri merkezin açık alanlarını kullanım zamanları

\begin{tabular}{|c|c|c|c|c|c|}
\hline & & \multicolumn{4}{|c|}{ Hastane bahçesini kullanım zamanı (\%) } \\
\hline & & $\begin{array}{c}\text { 10.00-14.00 } \\
\text { Arası }\end{array}$ & $\begin{array}{c}\text { 14.00-18.00 } \\
\text { Aras1 }\end{array}$ & $\begin{array}{c}\text { 18.00-22.00 } \\
\text { Arası }\end{array}$ & $\begin{array}{l}22.00 \text { ve } \\
\text { Sonrası }\end{array}$ \\
\hline \multirow{4}{*}{$\begin{array}{l}\text { Refakat } \\
\text { resi }\end{array}$} & 0-12 Saat Arası & 50 & 20 & 20 & 10 \\
\hline & 12-24 Saat Arası & 38 & 25 & 25 & 13 \\
\hline & 1-5 Gün Arası & 33 & 33 & 0 & 33 \\
\hline & 5 Günden Fazla & 17 & 67 & 17 & 0 \\
\hline
\end{tabular}

Refakatçilerin merkezin açık alanlarından memnuniyeti sorulduğunda ise, merkezde kalış süresi arttıkça beklentilerin arttığı ve memnuniyet seviyesinin azaldığg söylenebilir (Tablo 11).

Tablo 11. Refakatçilerin refakat süresi ve merkezin açı alan memnuniyeti arasındaki ilişki

\begin{tabular}{llccc}
\hline & \multicolumn{3}{c}{$\begin{array}{c}\text { Gazi Üniversitesi Sağlik Araştırma ve Uygulama Merkezi Açık } \\
\text { Alanlarından Memnuniyet (\%) }\end{array}$} \\
\cline { 2 - 5 } & $\begin{array}{c}\text { Evet, Memnunum Ye- } \\
\text { terli Geliyor }\end{array}$ & $\begin{array}{c}\text { Evet, Memnunum } \\
\text { Ancak Geliştirilebilir }\end{array}$ & $\begin{array}{c}\text { Hayır, Memnun De- } \\
\text { gilim }\end{array}$ \\
\hline \multirow{nyyyy}{*}{ Refakat süresi Saat Arası } & 20 & 70 & 10 \\
\cline { 2 - 5 } & 12-24 Saat Arası & 13 & 50 & 38 \\
\cline { 2 - 5 } & 1-5 Gün Arası & 0 & 67 & 33 \\
\cline { 2 - 5 } 5 Günden Fazla & 0 & 50 & 50 \\
\hline
\end{tabular}


Ankete katılan refakatçilerin hastanede kalma süreleri arttıkça açık alanları kullanım biçimleri daha çok oturma, dinlenme ve yeme içme ihtiyaçlarını karşılamaya yönelik aktivitelerden oluşmakta, kısa süreli refakatlerde alan genellikle otopark ihtiyacını karşılamak üzere kullanılmaktadır. Kısa süreli (0-12 saat) alan kullanımlarında, kullanım amaçları farklılaşsa bile mevcut koşulların refakatçileri memnun ettiği, bazı koşulların ise iyileştirilebileceği gözlenmektedir. Alanı 12-24 saat kullanan refakatçiler açısından memnuniyet azalmakta, alanı özellikle bekleme amacıyla kullanan kullanıcılar hâlihazırdaki koşulların geliştirilmesi gerektiğini vurgulamaktadır. Uzun süreli (1-5 gün ve 5 günden fazla) refakatçilerin hastane açık alanlarını kullanım oranı diğer refakatçilere göre daha fazladır. Bu kullanıcılar alanı daha çok dinlenme, zaman geçirme, bekleme ve yeme içme alanı olarak kullanmaktadırlar. Bu imkânların alanda kullanıcılara sunuluyor olması memnuniyet yaratmakta ancak kullanicılar tarafından gerek sunum kalitesi gerekse nicel açılardan bu olanakların geliştirilmesi gerekliliği dile getirilmektedir (Tablo 12). Alanın geliştirilmesi gerektiğini düşünen ve mevcut durumundan memnun olmayan refakatçilerden alınan geri dönüşlere göre; hastanede öncelikli olarak açık yeşil alanların ve oturma alanlarının miktarı arttırılmalı ve yaya taşıt karmaşası giderilmelidir. Bu önerileri yeme içme mekânlarının arttırılması ve çocuk oyun alanlarının eklenmesi takip etmektedir (Şekil 9).

Tablo 12. Refakatçilerin refakat süresi, açık alanları kullanımı ve memnuniyet durumları arasındaki ilişki (\%)

\begin{tabular}{|c|c|c|c|c|}
\hline \multirow{2}{*}{ Refakat Süresi } & \multirow{2}{*}{ Kullanım Biçimi } & \multicolumn{3}{|c|}{ Memnuniyet Durumu } \\
\hline & & Mem- & Memnun değil & Memnun, ancak geliştirile- \\
\hline \multirow{4}{*}{$0-12$ saat } & Otopark alanı & 33 & & 67 \\
\hline & Dinlenme alanı & & 50 & 50 \\
\hline & Bekleme alanı & & & 100 \\
\hline & Toplam & 20 & 10 & 70 \\
\hline \multirow{4}{*}{$12-24$ saat } & Otopark alanı & & 50 & 50 \\
\hline & Dinlenme alanı & 100 & & \\
\hline & Bekleme alanı & & 33 & 67 \\
\hline & Toplam & 13 & 38 & 50 \\
\hline \multirow{4}{*}{ 1- 5 gün } & Dinlenme alanı & & & 100 \\
\hline & Bekleme alanı & & 67 & 33 \\
\hline & Diğer & & & 100 \\
\hline & Toplam & & 33 & 67 \\
\hline \multirow{4}{*}{5 günden fazla } & Dinlenme alanı & & 50 & 50 \\
\hline & Bekleme alanı & & 33 & 67 \\
\hline & Yeme içme alanı & & 100 & 0 \\
\hline & Toplam & & 50 & 50 \\
\hline
\end{tabular}




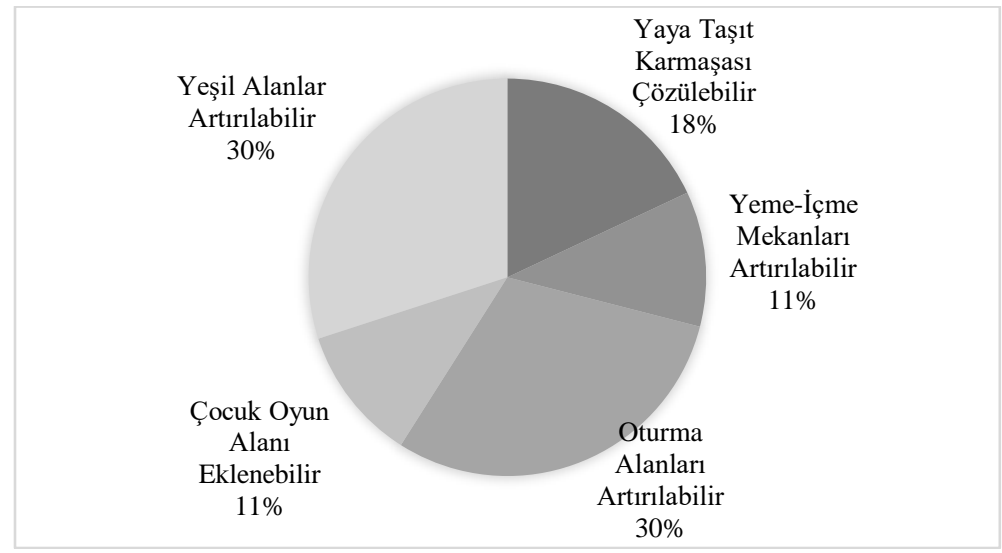

Şekil 9. Refakatçilerin Hastane Açık Alanlarından Beklentileri

\section{Ziyaretçi Anketlerinin Değerlendirilmesi}

Gazi Üniversitesi Hastanesine hasta ziyareti için gelen ziyaretçiler ile yapılan anketlerde yaş dağılımına bakıldığında katılımcıların \%87'sinin 2150 yaş aralığında, \%13'ünün ise 51 yaş ve üzerinde olduğu görülmüştür (Şekil 10.).

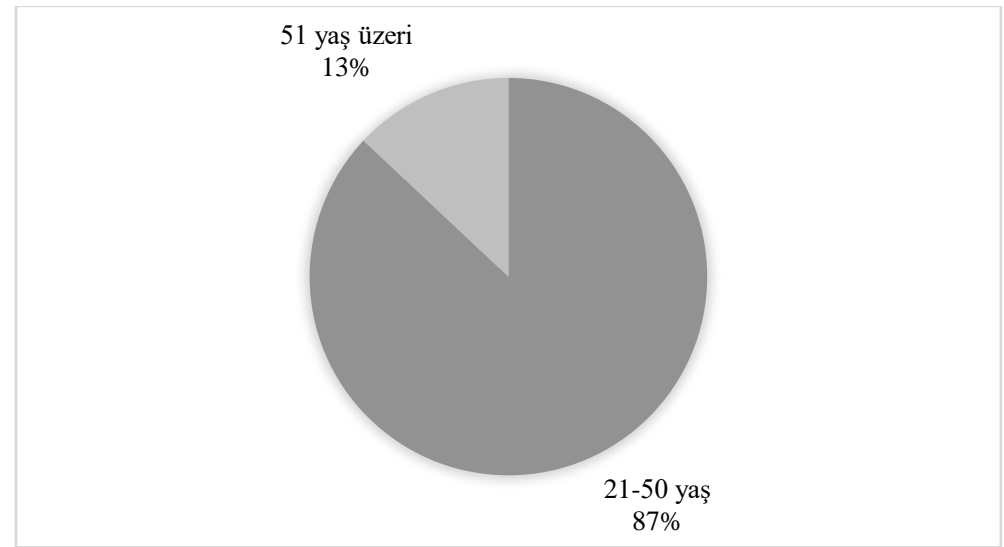

Şekil 10. Ziyaretçilerin Yaş Dağı̆lımı

Ankete katılan ziyaretçilerin \%90'1 daha önceden de hastaneye ziyarete geldiklerini belirtmişlerdir. En çok ziyaret edilen kişiler 1. derece akrabalar olurken, bu kişiler için ziyaret saatleri diğer yakınlık derecesindeki hastalara oranla daha uzun olmaktadır. Tüm hastalar için, yakınlık derecesine bakılmaksızın, bir değerlendirme yapılacak olursa ortalama ziyaret süresinin 15-30 dakika olduğu görülmektedir (Tablo 13). 
Tablo 13. Ziyaret edilen hasta ile yakınlık derecesi ve ziyaret süresi ilişkisi (\% kişi sayısı)

\begin{tabular}{lccccc}
\hline & \multicolumn{5}{c}{ Ziyaret süresi } \\
\cline { 2 - 6 } & $\begin{array}{c}0-15 \\
\text { dakika }\end{array}$ & $\begin{array}{c}15-30 \\
\text { dakika }\end{array}$ & $\begin{array}{c}30 \text { da- } \\
\text { kika- } 1 \\
\text { saat }\end{array}$ & $\begin{array}{c}1-2 \\
\text { saat }\end{array}$ & $\begin{array}{c}2 \text { saat- } \\
\text { ten fazla }\end{array}$ \\
\hline 1. Derece akraba (anne, baba, kardeş vb.) & 21 & 26 & 5 & 26 & 21 \\
\hline Uzak akraba & - & 100 & - & - & - \\
\hline Arkadaş, iş arkadaşı & 40 & 40 & 20 & - & - \\
\hline Toplam & 27 & 33 & 10 & 17 & 13 \\
\hline
\end{tabular}

Gün içinde ziyaret saatleri incelendiğinde ise ziyaretlerin genellikle 14.0018.00 saatleri arasında yoğunlaştığı, bu zaman aralığını iş sonrası saatlerini de kapsayan 18.00-22.00 saatlerinin izlediği söylenebilir. Hastaneye geliş saatleri ile açık alanların kullanım amaçları arasındaki ilişkiye bakıldığında; erken saatlerdeki gelişlerde ve iş çıkışı sonrası ziyaret saatlerinde (06.00-10.00, 10.00-14.00, 18.00-22.00 saatleri aras1) geçiş alanı ve otopark alanı olarak kullanıldığı, ziyaretlerin en yoğun olduğu zaman aralığı olan 14.00-18.00 saatleri arasında ise alanın daha çok bekleme alanı olarak kullanıldığı görülmektedir (Tablo 14).

Tablo 14. Ziyaret saati ve açık alan kullanım ilişkisi (\% kişi sayısı)

\begin{tabular}{|c|c|c|c|c|c|c|c|c|}
\hline & & $\begin{array}{l}\text { Hasta- } \\
\text { neye } \\
\text { girmek } \\
\text { için ge- } \\
\text { çiş alanı } \\
\text { olarak }\end{array}$ & $\begin{array}{c}\text { Otopark } \\
\text { olarak }\end{array}$ & $\begin{array}{c}\text { Bekleme } \\
\text { alanı } \\
\text { olarak }\end{array}$ & $\begin{array}{l}\text { Hasta } \\
\text { ile gö- } \\
\text { rüşme } \\
\text { alanı } \\
\text { olarak }\end{array}$ & $\begin{array}{c}\text { Hasta } \\
\text { refakat- } \\
\text { çileri ile } \\
\text { görüşme } \\
\text { alanı } \\
\text { olarak }\end{array}$ & $\begin{array}{l}\text { Yeme- } \\
\text { içme } \\
\text { alanı } \\
\text { olarak }\end{array}$ & $\begin{array}{c}\text { Din- } \\
\text { lenme } \\
\text { alanı } \\
\text { olarak }\end{array}$ \\
\hline \multirow{3}{*}{$\begin{array}{l}6.00- \\
10.00 \\
\text { aras1 }\end{array}$} & Satır & 40 & 40 & - & - & - & 20 & - \\
\hline & Sütun & 11 & 14 & - & - & - & 16 & - \\
\hline & Fre- & 2 & 2 & - & - & - & 1 & - \\
\hline \multirow{3}{*}{$\begin{array}{l}10.00- \\
14.00 \\
\text { aras1 }\end{array}$} & Satır & 33 & 33 & 16 & - & - & 8 & 8 \\
\hline & Sütun & 22 & 28 & 18 & - & - & 16 & 10 \\
\hline & Fre- & 4 & 4 & 2 & - & - & 1 & 1 \\
\hline \multirow{3}{*}{$\begin{array}{l}14.00- \\
18.00 \\
\text { arası }\end{array}$} & Satır & 20 & 17 & 27 & - & 6 & 10 & 17 \\
\hline & Sütun & 33 & 35 & 72 & - & 100 & 50 & 50 \\
\hline & Fre- & 6 & 5 & 8 & - & 2 & 3 & 5 \\
\hline \multirow{3}{*}{$\begin{array}{l}18.00- \\
22.00 \\
\text { arası }\end{array}$} & Satır & 35 & 21 & 7 & 7 & - & 7 & 21 \\
\hline & Sütun & 27 & 21 & 9 & 100 & - & 16 & 30 \\
\hline & Fre- & 5 & 3 & 1 & 1 & - & 1 & 3 \\
\hline \multirow{3}{*}{$\begin{array}{l}22.00 \\
\text { ve } \\
\text { son- } \\
\text { ras1 }\end{array}$} & Satır & 50 & - & - & - & - & - & 50 \\
\hline & Sütun & 5 & - & - & - & - & - & 10 \\
\hline & Fre- & 1 & - & - & - & - & - & 1 \\
\hline
\end{tabular}


Ziyaretçilerin hastane açık alanlarını kullanım amaçları sorgulandığında, ilk iki sırada bu alanların geçiş alanı ve otopark olarak kullanıldığı görülmektedir. Hastalar ile görüşme amaçlı kullanım ise son sıradadır (Şekil 11). Buna karşın ziyaretçilerin bu alanları öncelikli kullanım istekleri sorulmuş; alınan yanıtlarda; hastalar ve hasta refakatçileri ile görüşme alanı olarak kullanım isteği ilk sıralarda yer almakta, mevcut kullanım durumu (giriş /geçiş alanı ve otopark alanı olarak kullanım) en son tercih edilen kullanım biçimi olarak dikkat çekmektedir (Şekil 12).

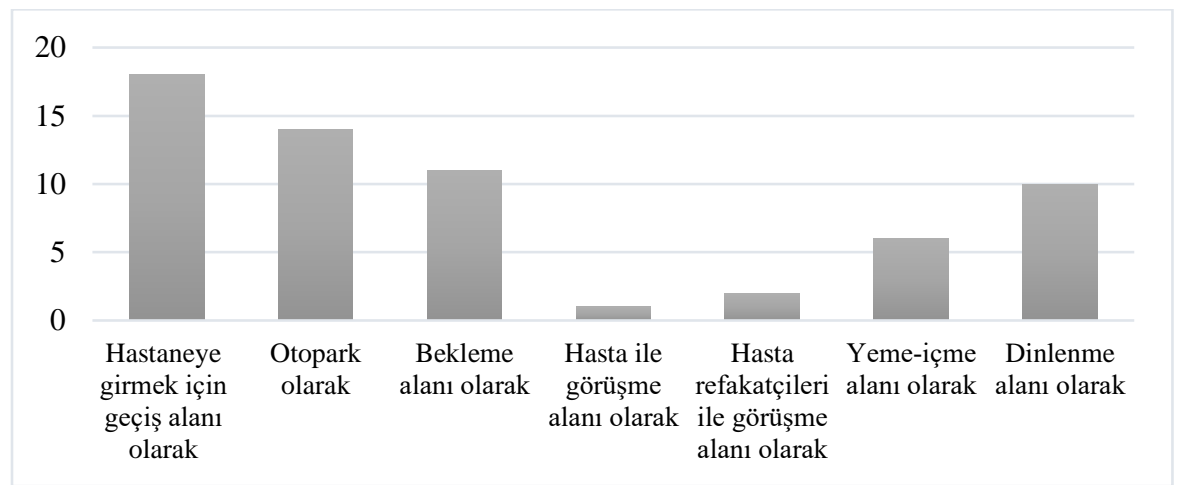

Şekil 11. Ziyaretçilerin hastane açık alanlarını kullanım amaçları

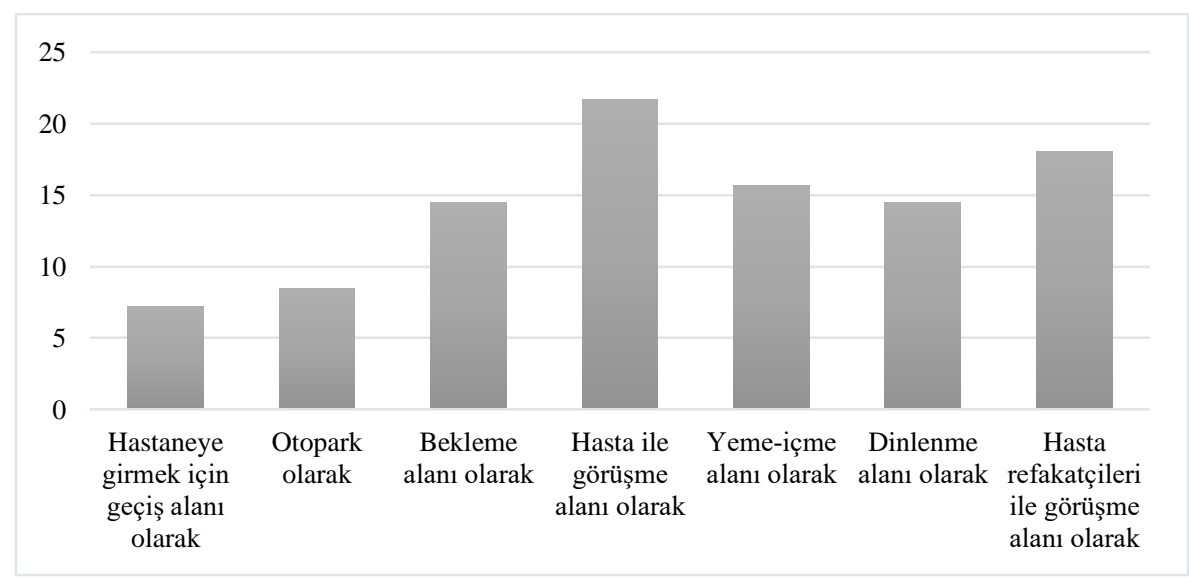

Şekil 12. . Ziyaretçilerin hastane açık alanlarını kullanım amacı tercihleri

\section{Hastane personeli anketlerinin değerlendirilmesi}

Gazi Üniversitesi Sağlık Araştırma ve Uygulama Merkezi'ndeki personel anketleri \%33'ü akademik personel, \%27'si idari personel, \%23'ü hizmet personeli ve \%17'si ise sağlık personeli tarafından yanıtlanmıştır (Şekil 13). 


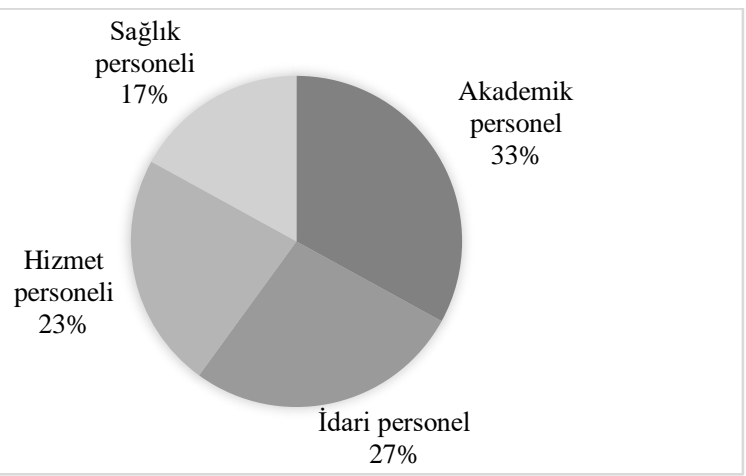

Şekil 13. Hizmet Birimine Göre Personel Anketi Dağılımları

Anket yapılan personele merkezde geçirdikleri süreyi belirlemek amacı ile haftalık çalışma süresi sorulmuş, en yoğun çalışma aralığının haftalık 30-40 saat arası olduğu görülmüştür. Sağlık personelinin ve idari personelin çoğunlukla haftalık 40-50 saat arası, akademik personelin haftalık 50 saatten fazla ve hizmet personelinin $30-40$ saat ve 50 saatten fazla çalışma süreleri olduğu belirlenmiştir (Tablo 15).

Tablo 15. Personellerin birimleri ve haftalık çalışma süreleri arasındaki ilişki

\begin{tabular}{llcccc}
\hline & & \multicolumn{3}{c}{ Haftalık çalışma süresi (\%) } \\
\cline { 3 - 6 } & $\begin{array}{c}\text { 30 Saatten } \\
\text { Daha Az }\end{array}$ & $\begin{array}{c}\text { 30-40 Saat } \\
\text { Arası }\end{array}$ & $\begin{array}{c}\text { 40-50 Saat } \\
\text { Arası }\end{array}$ & $\begin{array}{c}\text { 50 Saatten } \\
\text { Fazla }\end{array}$ \\
\hline \multirow{2}{*}{$\begin{array}{l}\text { Perso- } \\
\text { nel } \\
\text { birimi }\end{array}$} & Sağllk Personeli & - & 20 & 60 & 20 \\
\cline { 2 - 6 } & İdari Personel & 13 & 37 & 50 & - \\
\cline { 2 - 6 } & Akademik Personel & 20 & 30 & 10 & 40 \\
\hline & Hizmet Personeli & 14 & 43 & - & 43 \\
\hline
\end{tabular}

Hastanede çalışan ve ankete katılan personelin; birimleri ve çalışma süreleri analiz edildikten sonra, birimlerine ve hastanede geçirdikleri zamana göre açık alan kullanım biçimlerinde bir farklılık olup olmadığı analiz edilmeye çalışılmıştır. Sağlık personeli ve idari personelin hastane açık alanlarını kullanım aralığı ve kullanım amaçları benzer nitelikler göstermektedir. Her iki grup için de açık alanları öncelikli kullanım amacı otopark ihtiyaçlarını karşılamak olarak görülmektedir. Her iki grubun da hastanede bulunduğu süre haftalık 40-50 saatlik bir zaman dilimini kapsamaktadır. Bu gruplar için öncelikli açık alan kullanım amaçları bekleme ve dinlenme aktiviteleri olarak görülmektedir. Akademik personel hastanede en uzun süreli zaman geçiren gruptur ve açık alan kullanım amaçları otopark ihti- 
yacını karşılama ve dinlenme aktivitelerini gerçekleştirme olarak gözlenmektedir. Hastanede çalışan hizmet personelinin ise açık alanları çoğunlukla dinlenme amaçlı kullandıkları sonucu elde edilmiştir (Tablo 16).

Tablo 16. Hastane personelinin görev birimi, çalışma saatleri ve açık alan kullanım amaçları arasındaki ilişki (\%)

\begin{tabular}{|c|c|c|c|c|c|}
\hline & & $\begin{array}{c}\text { Otopark } \\
\text { olarak }\end{array}$ & $\begin{array}{c}\text { Bekleme } \\
\text { alanı ola- } \\
\text { rak }\end{array}$ & $\begin{array}{c}\text { Dinlenme } \\
\text { alanı olarak }\end{array}$ & $\begin{array}{c}\text { Yeme içme } \\
\text { alanı ola- } \\
\text { rak }\end{array}$ \\
\hline \multirow{4}{*}{$\begin{array}{l}\text { Sağlik perso- } \\
\text { neli }\end{array}$} & 30-40 saat & - & 100 & - & - \\
\hline & $40-50$ saat & - & 67 & 33 & - \\
\hline & 50 saatten fazla & - & 100 & 0 & - \\
\hline & Toplam & - & 80 & 20 & - \\
\hline \multirow[t]{4}{*}{ İdari personel } & 30 saatten az & 100 & - & - & - \\
\hline & 30-40 saat & 67 & - & 33 & - \\
\hline & $40-50$ saat & 75 & 25 & - & - \\
\hline & Toplam & 74 & 13 & 13 & - \\
\hline \multirow{5}{*}{$\begin{array}{l}\text { Akademik } \\
\text { personel }\end{array}$} & 30 saatten az & 50 & - & 50 & - \\
\hline & $30-40$ saat & 33 & - & 67 & - \\
\hline & 40-50 saat & 100 & - & - & - \\
\hline & 50 saatten fazla & 50 & - & 25 & 25 \\
\hline & Toplam & 50 & - & 40 & 10 \\
\hline \multirow{4}{*}{$\begin{array}{l}\text { Hizmet perso- } \\
\text { neli }\end{array}$} & 30 saatten az & - & 100 & - & - \\
\hline & $30-40$ saat & 33 & - & 67 & - \\
\hline & 50 saatten fazla & - & 33 & 34 & 33 \\
\hline & Toplam & 14 & 28 & 44 & 14 \\
\hline \multirow[t]{5}{*}{ Toplam } & 30 saatten az & 50 & 25 & 25 & - \\
\hline & $30-40$ saat & 40 & 10 & 50 & - \\
\hline & 40-50 saat & 50 & 38 & 12 & - \\
\hline & 50 saatten fazla & 25 & 25 & 25 & 25 \\
\hline & Toplam & 40 & 23 & 30 & 7 \\
\hline
\end{tabular}

Anket katılan hastane personelinin açık alanları kullandıkları zaman dilimleri incelendiğinde tüm çalışanların en yoğun kullanım aralığı, öğle tatilini de kapsayan, 10.00-14.00 saatleri olarak görülmektedir. İkincil kullanım yoğunlukları açısından sağlık personeli aksam iş çıkış saatlerinde (18.00-22.00) açı alanları kullanırken, idari personelin sabah 6.00-10.00 aralığında, akademik personelin 14.00-18.00 diliminde, hizmet personelinin ise diğer zaman aralıklarında eşit oranlarda bu alanları kullandığı söylenebilir. (Tablo 17). 
Tablo 17. Hastane personelinin birimleri ve açık alanları kullanım zamanları arasındaki ilişki

\begin{tabular}{|c|c|c|c|c|c|c|}
\hline & \multicolumn{5}{|c|}{ Hastane bahçesini kullanım zamanları (\%) } \\
\hline & & $06.00-10.00$ & $10.00-14.00$ & $14.00-18.00$ & $18.00-22.00$ & $22.00 \mathrm{ve}$ \\
\hline & & Arası & Arası & Aras1 & Aras1 & Sonrasi \\
\hline \multirow{4}{*}{$\begin{array}{l}\text { Perso- } \\
\text { nel } \\
\text { birimi }\end{array}$} & Sağlik Personeli & - & 40 & 20 & 40 & - \\
\hline & İdari Personel & 26 & 38 & 12 & 12 & 12 \\
\hline & Akademik Personel & 10 & 40 & 30 & & 20 \\
\hline & Hizmet Personeli & & 58 & 14 & 14 & 14 \\
\hline
\end{tabular}

Gazi Üniversitesi Sağlık Araştırma ve Uygulama Merkezi'ndeki anket yapılan personelin hizmet birimine bakılmaksızın hastane açık alanlarından memnuniyetlerinin düşük olduğu söylenebilir. Memnun olduğunu söyleyen personelin de $\% 93$ 'ü bu alanların geliştirilebileceğini, yetersizliklerin tamamlanması gerektiğini dile getirmektedir (Tablo 18).

Tablo 18. Hastane personelinin hizmet birimleri ve personelin açık alanlardan memnuniyeti arasındaki ilişki

\begin{tabular}{lllcc}
\hline & \multicolumn{4}{c}{ Memnuniyet Durumu (\%) } \\
\cline { 3 - 5 } & & $\begin{array}{c}\text { Evet Memnunum, } \\
\text { Yeterli Geliyor }\end{array}$ & $\begin{array}{c}\text { Evet Memnunum, } \\
\text { Ancak Geliştirilebilir }\end{array}$ & $\begin{array}{c}\text { Hayır, } \\
\text { Memnun Değilim }\end{array}$ \\
\hline \multirow{2}{*}{$\begin{array}{l}\text { Personel } \\
\text { birimi }\end{array}$} & Sağlık Personeli & - & 60 & 40 \\
\cline { 2 - 5 } & İdari Personel & - & 50 & 50 \\
\cline { 2 - 5 } & Akademik Personel & - & 20 & 80 \\
\cline { 2 - 5 } & Hizmet Personeli & 14 & 58 & 28 \\
\cline { 2 - 5 } & Toplam & 4 & 43 & 53 \\
\hline
\end{tabular}

Ankete katılan ve açık alanların mevcut durumundan memnuniyetsizliklerini ya da bu alanların yetersizliklerini dile getiren personelin önerilerine göre öncelikle çözülmesi gereken problemler; yaya- taşıt karmaşası ve alanda vakit geçirmek, beklemek ve dinlenmek için gerekli olan oturma birimlerinin sayıca arttırılması gerekliliği olmuştur. Bu önerileri yeşil alan miktarının arttırılması izlemektedir (Şekil 14).

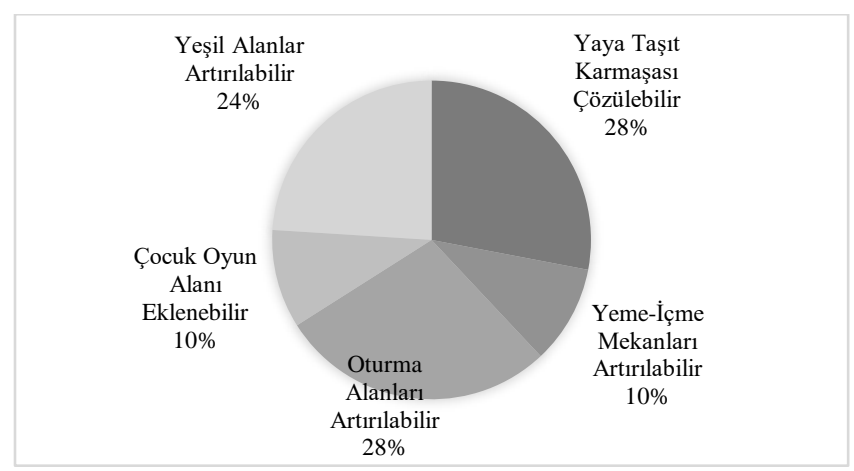

Şekil 14. Personelin Merkezin Açık Alanlarından Beklentileri 


\section{Öğrenci Anketlerinin Değerlendirilmesi}

Gazi Üniversitesi Sağlık Araştırma ve Uygulama Merkezi'nde bulunan ve ankete katılan öğrencilerin \%26'sı 1. 2. ve 3. sinıfta okuyan, \%40'ı stajyer (4. ve 5. sınıf) öğrenci, \%17'si intörn (6. sinıf), \%17si ise uzmanlık okuyan öğrenci statüsünde yer almaktadır (Şekil 15).

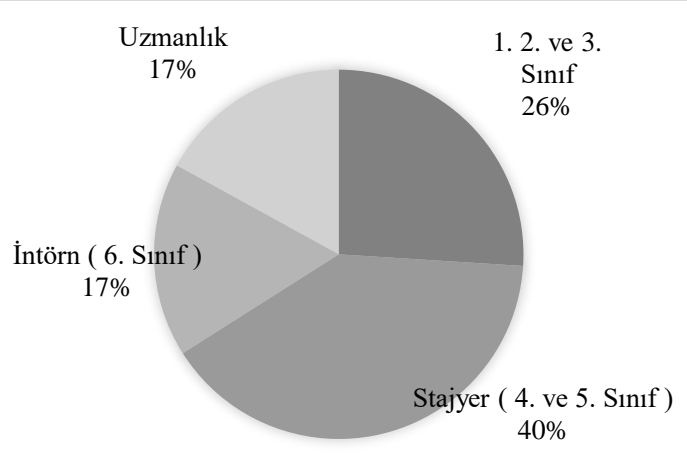

Şekil 15. Anket Yapılan Öğrencilerin Sınıfları

Anket yapılan öğrencilere ders saatleri harici günlerinin ne kadarını hastane alanı içerisinde geçirdikleri sorulduğunda en fazla 1-3 saat arası bir süreyi merkezde geçirdikleri ve bu süreyi en fazla stajyerlerin geçirdiği sonucu elde edilmiştir. 1., 2. ve 3. sınıf öğrencilerinin hastanede geçirdikleri süre 30 dakika-1 saat arasında iken uzmanlık öğrencileri için bu süre ağırlıklı olarak yarım saatin altında kalmaktadır (Tablo 19).

Tablo 19. Öğrencilerin sınıfı ve merkezde ders harici geçirdiği süre arasındaki ilişki

Ders saatleri dışında hastanede geçen süre (\%

kişi sayısı)

\begin{tabular}{clcccc} 
& & $\begin{array}{c}\text { 30 Daki- } \\
\text { kadan Az }\end{array}$ & $\begin{array}{c}\text { 30 Dakika- 1 } \\
\text { Sat Arasi }\end{array}$ & $\begin{array}{c}\text { 1-3 Saat } \\
\text { Arasi }\end{array}$ & $\begin{array}{c}\text { 3 Saatten } \\
\text { Fazla }\end{array}$ \\
\hline \multirow{2}{*}{ Öğrenci olunan sinıf } & 1. 2. ve 3. Sinıf & - & 50 & 37 & 13 \\
\cline { 2 - 6 } & Stajyer( 4. ve 5. Sinıf ) & - & 17 & 66 & 17 \\
\cline { 2 - 6 } & İntörn (6. Sinıf ) & - & 40 & 40 & 20 \\
\cline { 2 - 6 } & Uzmanl1k & 60 & 20 & - & 20 \\
\hline Toplam & 10 & 30 & 43 & 17 \\
\hline
\end{tabular}

Öğrencilerin okudukları sınıflara göre, merkezin açık alanlarını kullanım biçimleri, bu alanlardan memnuniyet durumları ve beklentileri belirlenmeye çalışılmıştır. Ankete katılan öğrenciler hastanede bulunan açı alanları daha çok yeme içme alanı olarak kullandıklarını, uzmanlık aşamasına gelmiş öğrenciler ise daha çok otopark amaçlı kullandıklarını dile getirmiştir (Tablo 20). Buna karşın hangi sınıfta olursa olsunlar tüm öğrenciler 
açık alanları dinlenme alanı olarak kullanmak istediklerini (Tablo 21) ve bunun için de öğrenciler için düzenlenmiş özel alanlara ihtiyaç duyduklarını, yeşil alanların arttırılması ve yaya taşıt karmaşasının çözülmesi gerekliliğini vurgulamışlardır (Şekil 16).

Tablo 20. Öğrencilerin sınıfı ve açık alanları kullanım amacı arasındaki ilişki

\begin{tabular}{|c|c|c|c|c|c|}
\hline & & \multicolumn{4}{|c|}{ Hastane bahçesini kullanım amacı (\%) } \\
\hline & & $\begin{array}{c}\text { Otopark } \\
\text { Alanı Olarak }\end{array}$ & $\begin{array}{c}\text { Dinlenme } \\
\text { Alanı Olarak }\end{array}$ & $\begin{array}{c}\text { Bekleme } \\
\text { Alanı Olarak }\end{array}$ & $\begin{array}{c}\text { Yeme İçme } \\
\text { Alanı Olarak }\end{array}$ \\
\hline \multirow{5}{*}{$\begin{array}{l}\text { Öğrenci de- } \\
\text { vam ettik- } \\
\text { leri sinıf }\end{array}$} & 1. 2. ve 3. Sinif & - & 37 & 13 & 50 \\
\hline & Stajyer ( 4. ve 5 . Sinıf ) & 25 & 25 & 17 & 33 \\
\hline & İntörn (6. Sinıf ) & 40 & 20 & - & 40 \\
\hline & Uzmanlık & 60 & - & 20 & 20 \\
\hline & Toplam & 27 & 23 & 13 & 37 \\
\hline
\end{tabular}

$\underline{\text { Tablo 21. Öğrencilerin sınıfı ve açık alanları kullanmak istediği amaç arasındaki ilişki }}$

\begin{tabular}{|c|c|c|c|c|c|}
\hline & & \multicolumn{4}{|c|}{ Hastane bahçesini kullanım amacı isteği (\%) } \\
\hline & & $\begin{array}{c}\text { Otopark } \\
\text { Alanı Olarak }\end{array}$ & $\begin{array}{c}\text { Dinlenme } \\
\text { Alanı Ola- } \\
\text { rak }\end{array}$ & $\begin{array}{c}\text { Bekleme } \\
\text { Alanı Olarak }\end{array}$ & $\begin{array}{c}\text { Yeme İçme } \\
\text { Alanı Olarak }\end{array}$ \\
\hline \multirow{5}{*}{$\begin{array}{l}\text { Öğrenci } \\
\text { devam et- } \\
\text { tikleri s1- } \\
\text { nıf }\end{array}$} & 1. 2. ve 3. Sinif & - & 50 & 13 & 37 \\
\hline & Stajyer( 4. ve 5 . Sinıf ) & - & 84 & 16 & - \\
\hline & İntörn (6. Sinıf ) & - & 50 & - & 50 \\
\hline & Uzmanlık & 17 & 66 & - & 17 \\
\hline & Toplam & 3 & 67 & 10 & 20 \\
\hline
\end{tabular}

\begin{tabular}{|c|c|}
\hline $\begin{array}{c}\text { Yaya Taşıt } \\
\text { Karmaşası } \\
\text { Çözülebilir } \\
21 \%\end{array}$ & $\begin{array}{cc}\text { Yeme-İçme } & \\
\text { Mekanları } & \\
\text { Artırılabilir } & \text { Oturma } \\
14 \% & \text { Alanları } \\
& \text { Artırılabilir } \\
7 \%\end{array}$ \\
\hline $\begin{array}{c}\text { Yeşil Alanlar } \\
\text { Artırılabilir } \\
31 \%\end{array}$ & $\begin{array}{c}\text { Öğrenciler İçin } \\
\text { Özel Mekanlar } \\
27 \%\end{array}$ \\
\hline
\end{tabular}

Şekil 16. Anket Yapılan Öğrencilerin Gazi Üniversitesi Sağlık Araştırma ve Uygulama Merkezi Açık Alanlarından Beklentileri

\section{Tartıșma}

Literatür araştırmalarında da belirtildiği gibi doğru tasarlanmış hastane açık alanlarının gerek sağlık üzerindeki olumlu etkileri gerekse kentsel mekâna katkıları, bu alanları tasarım ve uygulama süreçlerinde öncelikli ele alınması 
gerekli alanlar haline getirmektedir. Süreçte önemli olan, açık alanların, binaların tasarlanması süreci ile paralel ele alınması ve bütüncül bir yaklaşımla tasarlanmasıdır. Fiziksel ve görsel erişilebilirlik, yakınlık ve anlaşılabilirlik gibi mekânsal nitelikler ve bunların yanı sıra doğal değerlerin dikkate alındığı (güneş, ağaçlar, çiçekler, su, gölge, sıcaklık gibi) düzenlemeler bu alanlar için yapılabilecek en temel uygulamalardır.

Sağlık alanlarının açık alan kullanım biçimlerinin ve sağlık üzerindeki olumlu etkilerinin, kullanıcıların yanı sıra doktorlar, varsa bu alanları kullanan öğrenciler ve çalışan personel açısından da iş performansını arttırıcı nitelikleri dikkate alınmalıdır. Türkiye'nin nitelikli sağlık hizmeti sunan kurumları arasında yer alan Gazi Üniversitesi Hastanesi sayılan tüm kullanıcı gruplarını bünyesinde bulundurmakta ve geniş bir spektrumda hizmet vermektedir. Bu bakış açısı ile ele alındığında ve sahip olduğu kullanıcı çeşitliliği göz önünde bulundurulduğunda hastane açık alanlarının tüm bu farklı kullanıcı gruplarına hizmet verecek şekilde tasarlanması önem kazanmaktadır. Mevcut durumda böyle bir ayrım bulunmamaktadır. Ancak hastanenin içinde bulunduğu mekânsal yenilenme süreci açık alanların yeniden tasarlanması ve bu süreçte eksikliklerin tamamlanması, arzu edilen düzenlemelerin yapılması açısından bir fırsat yaratmaktadır.

Yapılan anketler ve sözlü görüşmeler sonrasında elde edilen temel veriler göstermektedir ki hastane açık alanları kısmen belirli ihtiyaçlara yanıt verse de mevcut durumu ile kullanıcılarının ihtiyaçlarını karşılayamamaktadır (Tablo 22). Tüm kullanıcılar bu alanları özellikle dinlenme amaçlı kullanmak istediklerini dile getirmişler, ilk çözülmesi gereken problemin ise taşıt-yaya karmaşası olduğunu belirtmişlerdir. Ayrıca hastalar açısından da doğa ile etkileşimde bulunabilecekleri alanlar yaratılması yenilenme sürecinde ele alınması gereken önemli bir detaydır. Dolayısıyla açı alanların tasarlanması sürecinde; yaya öncelikli mekânların oluşturulduğu, kontrol ve güven hissinin yaratıldığı, fiziksel hareket ve egzersiz olanaklarının sunulduğu ve doğa ile etkileşim kurulabilecek ortamların yer aldığı dinlenme mekânlarının yaratılması, örnek olarak ele alınan hastane kampüs alanı için öncelikli hedefler olarak belirlenmelidir. Literatür çalışmalarında da vurgulandığı gibi, hastane açık alanlarının bilinmesi ve görsel olarak geçirgen olması, herkes için erişilebilir olması, aktif ve pasif kullanıma olanak vermesi, aydınlatılması, iklim etkilerinin (güneş, rüzgâr, yağmur vb.) dikkate alınarak tasarlanması ve ses yalıtımının sağlanması tasarım süreçlerinde dikkate alınması gereken önemli niteliklerdir. 
Tablo 22. Gazi Hastanesi açık alanlarının tasarım kriterleri açısından değerlendirilmesi

Fiziksel hareket olanakları
Hastane açık alanlarının öncelikli kullanım biçimi
otopark olduğu için, kullanıcılara yönelik, fiziksel
hareketi teşvik edecek bir düzenlemeden söz edile-
memektedir.

\section{Erişilebilirlik}

Hastane açık alanları mevcut durumunda engelli kişilerin kullanımı için özel düzenlemelere sahip olmamasına (engellilere uygun oturma mekanları, masalar vb.) karşın herkes için erişilebilir mekanlar olarak düzenlenmişlerdir.

\section{Doğa ile etkileşim}

Alandaki mevcut yeşil doku kullanıcılara doğa ile iletişim kurdukları hissini kısıtlı da olsa vermektedir. Bu alanlar için temel problem, kullanıcılar için düzenlenmiş olan oturma ve dinlenme alanlarının araç yollarının ortasında, dolayısıyla taşıt trafiğinin etkisinde olması olarak belirtilebilir.
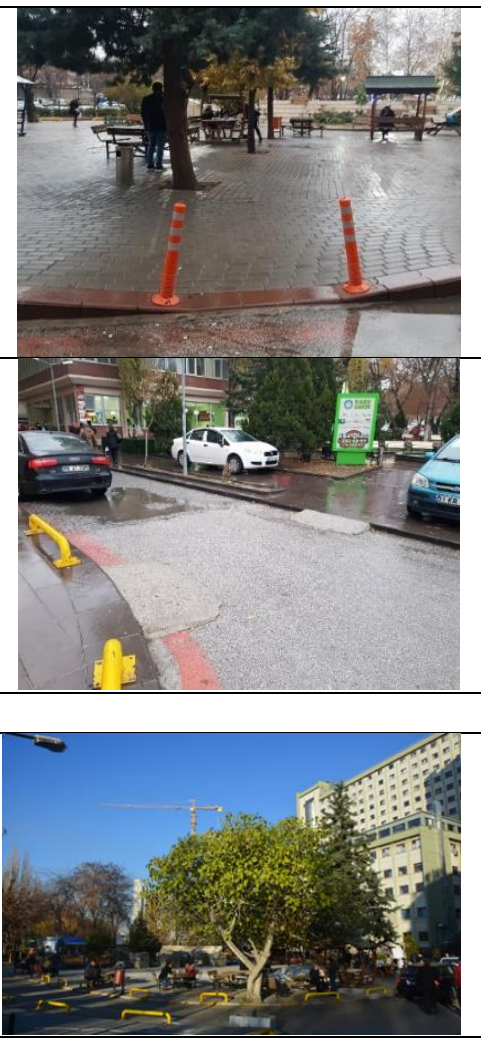


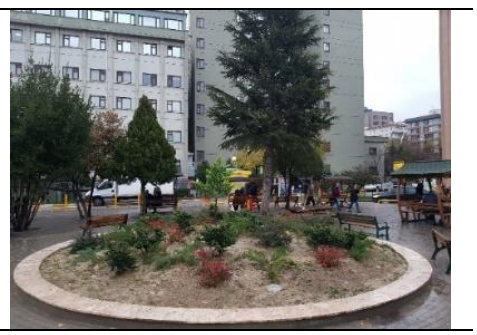

\section{Görsel geçirgenlik}

Tüm açık kullanım alanları konumları itibariyle görsel olarak geçirgendirler.

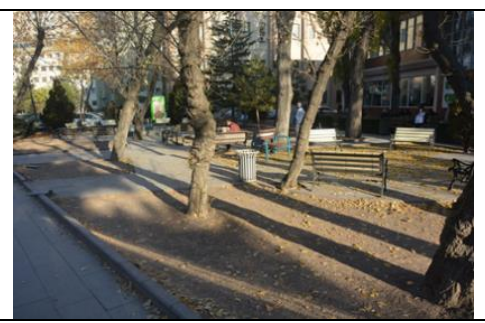

\section{Aktif ve pasif kullanım olanakları}

Hastane kullanıcılarının vakit geçirmeleri için düzenlenmiş açık alanlar gerek aktif gerekse pasif kullanıma olanak verecek niteliktedir.

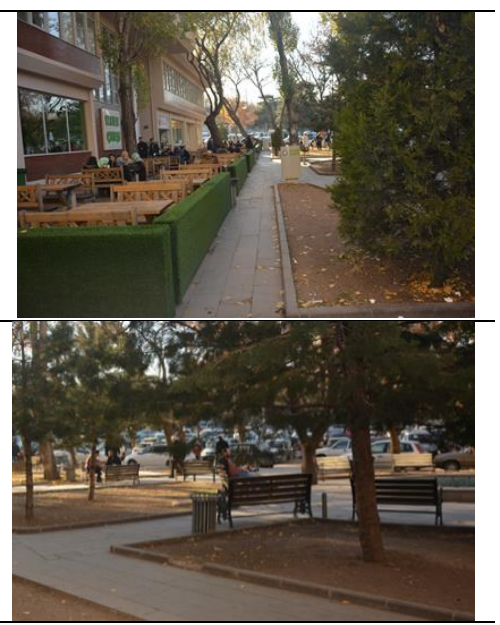

\begin{tabular}{l|l}
\hline Aydınlatma & \\
\hline Açık alanlardaki aydınlatmalar gece kullanımında \\
güvenlik hissini arttıracak biçimde geliştirilmelidir.
\end{tabular}




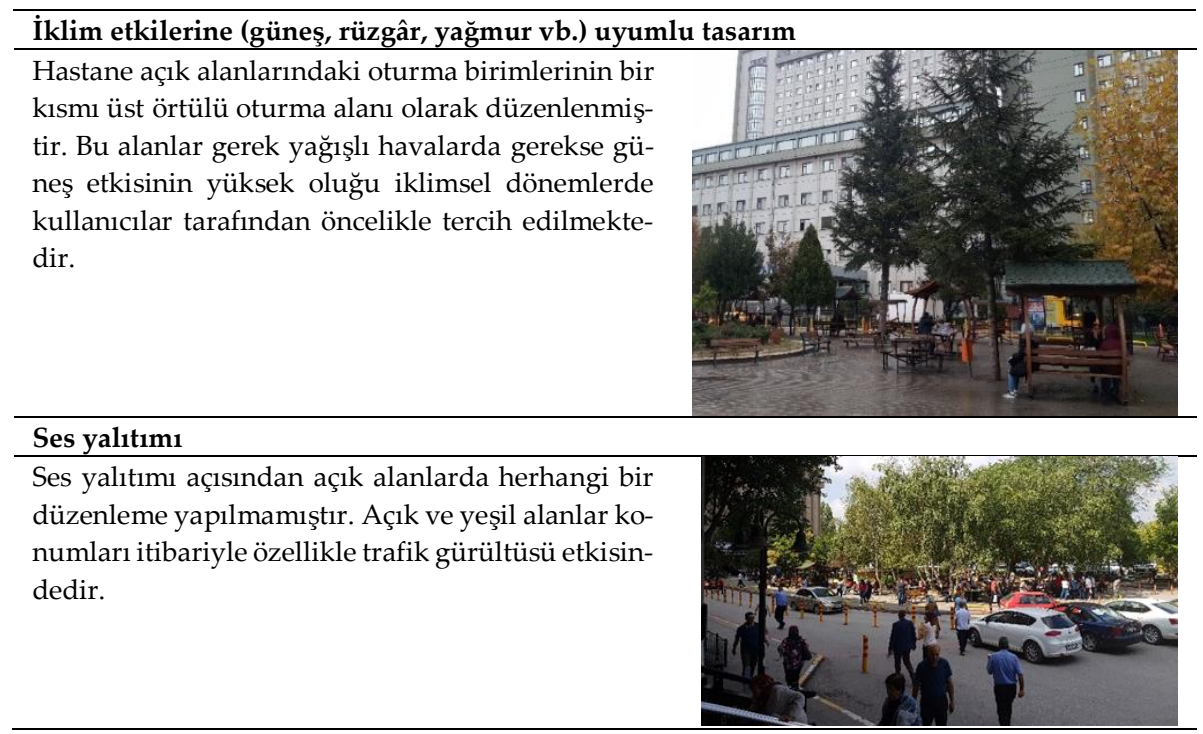

Gazi Üniversitesi Sağlık Araştırma ve Uygulama Merkezi özelinde uygulama açısından ele alındığında, yıkılması planlanan alanın kampüs alanına eklenmesiyle elde edilecek bölgenin, hastaların tedavilerine katkı sağlayabilecek şekilde ve kullanıcıların dinlenme isteklerini karşılamaya yönelik olarak tasarlanması ilk aşamada temel ihtiyaçların cevaplanmasina olanak verecektir. Yeni alan, konumu itibari ile trafik etkisinden uzak, hastaneye erişimde alternatif ulaşım imkânları sunacak, farklı kullanıcılara yönelik olarak özelleşmiş mekânlar yaratılmasına olanak sağlayacak form ve büyüklüktedir. Mevcut kullanımdaki trafik akışı düzenlenerek yaya-taşıt kesişmeleri en az seviyeye getirilmelidir. Bu düzenleme yaya olarak alana gelecek kullanıcılar açısından sirkülasyon sisteminin yeniden biçimlendirilmesi ile sağlanabilir. Yeni yaya sirkülasyon güzergahının yaratılacak yeni mekanlar ile ilişkilendirilmesi, bu alanların görünebilirliğini ve dolayısıyla bilinirliğini de sağlayacak, bu durum tasarlanan mekanların kullanımını da arttıracaktır. Tasarımda öncelikli konulardan bir diğeri de yeşil dokunun yoğunluğu ve kullanıcıların temel ihtiyacı olan dinlenme ve doğa ile etkileşim isteklerine yanıt vermek olmalıdır.

Mevcutta hastane alanında bulunan yeşil doku, hastanenin bulunduğu bölge açısından oldukça yoğun bir yeşil doku niteliğindedir. Ancak bu dokunun yoğun olduğu alanlar araçlar için otopark olarak kullanılmakta, hastane kullanıcıları için düzenlenmiş açık yeşil alan niteliği taşımamaktadır (Şekil 17). Mevcuttaki yeşil dokunun korunması ve hâlihazırda sert 
zemin olan alanların ihtiyaçları karşılayacak şekilde en aza indirilerek yeşil alanlara dönüştürülmesi ve bu alanlara terapi etkisi güçlü su ögesinin eklenmesi alanın kullanıcılar üzerindeki etkisini farklılaştıracaktır. Bu yeni düzenleme ile kaybedilecek otopark alanları ise yeni tasarlanacak açık ve yeşil alanlarda zemin altı otoparkları olarak çözümlenebilir. Ayrıca oturma ve dinlenme mekânlarında gölge etkisi yüksek ağaç türlerinin seçilmesi ve bina kenarlarında ölü cephelerde perde etkisi yaratacak yeşil dokunun tercih edilmesi kullanıcılar ile yapı cepheleri arasındaki görsel ilişkiyi azaltacak, doğa ile iç içe olunduğu hissini pekiştirecektir. Bu düzenleme aynı zamanda yapı içerisindeki kullanıcılar için de doğa ile görsel ilişki kurmak anlamına gelecektir ki özellikle tedavi süreçlerinde yataktan kalkamayan ve/veya odalarından çıkamayan hastalar için bu görsel bağ iyileşme süreçlerinde pozitif etki yaratacaktır.

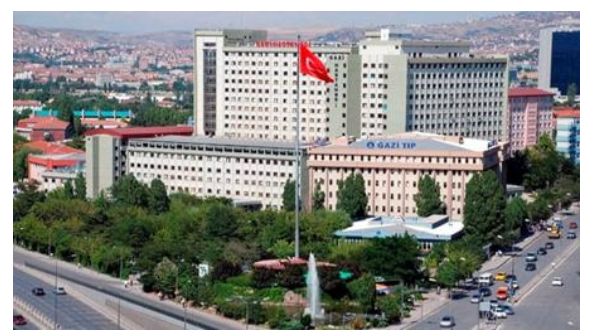

Kaynak: Gazete Duvar, 2018

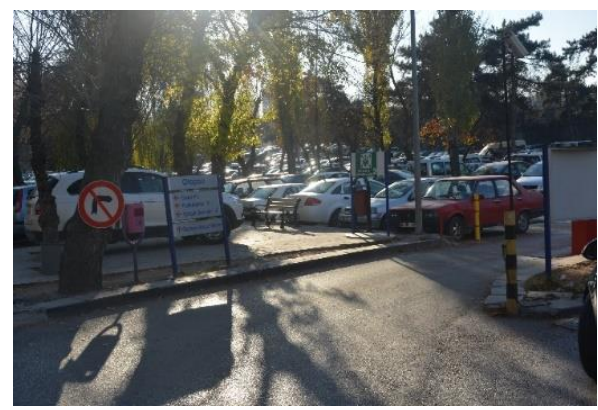

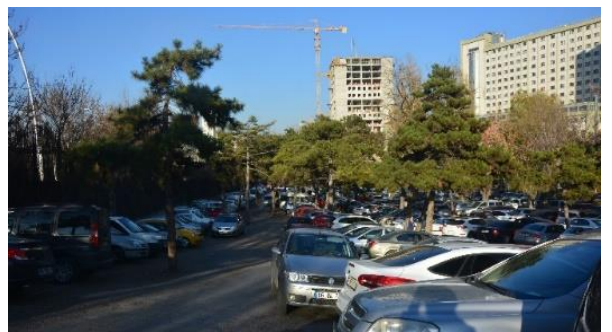

Kaynak: Kişisel arşiv

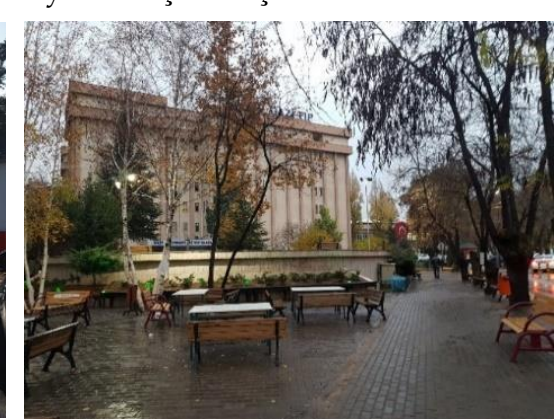

Şekil 17. Gazi Üniversitesi Hastanesi yeşil alanları

Mekânsal düzenlemeler yapılırken farklı yaş gruplarındaki ve farklı statülerdeki (doktor, çalışan, hasta, öğrenci vb.) kullanıcılar da dikkate alınarak, mekânsal kademelenme ile farklı seviyelerde mahremiyeti olan alanlar yaratılması tüm kullanıcıların isteklerinin karşılanmasında kolaylaştıııcı olacaktır. Bu aşamada kullanıcılardan gelen bir diğer talep olan; güvenli çocuk oyun alanlarının oluşturulması da, alanda mevcutta bulunan oyun alanının öncelikle yerseçimi açısından yeniden değerlendirilmesi gerekliliğini ortaya koymaktadır. 


\section{Sonuç}

Bulunduğu kentin kimliğini oluşturan bir öğe, kentliye sağlıklı yaşamının devamlığını sağlamaya yardımcı bir kamusal mekân olan hastaneler, açık ve kapalı mekânlarıyla bir bütün oluşturmaktadır. Bu bütünlügün sağlanmasının, hastanelerin temel amaçlarından biri olan iyileştirme görevini tamamlamasında önemli bir payı vardır. Kamusal mekânların ortak özelliklerinden biri olan farklı sosyal sınıflardan insanları ortak mekânlarda buluşturma işlevi, hastanelerde, özellikle de kullanıcıların zaman geçirdikleri ve aktif olarak kullandıkları hastane açık alanlarında çok net izlenebilir.

Sağlık kampüs alanlarının, sağlık birimlerinin, daha özelde ise hastanelerin mekânsal ihtiyaçlarının belirlenmesi, gerek kapalı gerekse açık alanların bu ihtiyaçlar doğrultusunda şekillendirilmesi ve inşası önemli bir tasarım sorunsalıdır. Süreçte, bir yandan farklı kullanıcı gruplarının ihtiyaçları dikkate alınırken, bir yandan da mekânsal niteliklerin ve yeterliliklerin müsaade ettiği ölçüde en doğru kararların alınması, planlama, uygulama ve yönetim aşamalarında etkin işleyişi sağlayacak ve kullanıcılar açısından da memnuniyet yaratacaktır.

Hastanelerin öncelikli işlevi olan hastalıkların teşhis ve tedavisi süreçlerinde her ne kadar temel ihtiyaç alanları son teknolojilere sahip yapılı alanlar olsalar da, açık ve yeşil alanların psikolojik etkileri ve bu etkiler aracilığı ile iyileşme süreçlerine katkıları göz ardı edilmemelidir. Bir başka bakış açısıyla; hastanelerin tasarlanması sürecinde yaratılan açık ve/veya yarı açık kamusal, yarı kamusal ve yarı özel mekânlar kişiler arası iletişim kurulmasında, sosyal ilişkilerin oluşmasında, iç ve dış mekânların bütünleşmesinde, hareket serbestliği yaratılmasında, doğa ile biraradalığı sağlamada, yaşayan güvenli mekânlar yaratmada, kent ile hastane arasındaki ilişkinin kurulmasında etkili araçlar olarak da önem kazanmaktadır.

Sayılan tüm bu nedenlerle, hastane mekanlarının ve bu mekanlarla ilişkilendirilecek açık alanların yaratılmasında; başarılı kentsel kamusal mekanlar için geçerli olan ilkelerin uygulanmasının yanı sıra, işlevin gerektirdiği temel gereklilikleri de (hasta mahremiyeti, farklılaşan kullanıcı ihtiyaçları, işlevsel mekânsal ilişkiler ve bağlantılar, hijyen vb.) dikkate alan bir tasarım esas olmalıdır. Süreçte engelli kullanıcıların ve dezavantajlı grupların, yaratılan yaşam alanlarını güvenli ve konforlu kullanımının sağlanması, kullanıcılara eşit imkânların sunulmasının sosyal eşitlik açısından önemi de unutulmamalıdır. 


\section{Extended Abstract}

\section{Determining the Needs of use and Design Principles of Open Spaces in Urban Hospitals}

$*$

\section{Nilüfer Gürer \\ Akdeniz University}

Health services which have different dimensions like patient care, diagnosis and treatment of diseases, administrative services, education etc. are generally offered within the same building or in a complex or campus because they cannot be separated spatially. The primary services are patient acceptance, disease diagnosis and treatment processes in health complexes and all these services and healing processes of patients are directly influenced by the quality of open spaces of the buildings and their architectural qualities. Therefore, the physical qualities of the health complexes are also affecting the results of health services provided.

Hospitals, especially those serving at the urban scale and the regional scale, have many different units and functions. Each of these functions requires different spatial needs, brings together different groups of users, thus raising different open space requirements. However, rapidly increasing settled areas and private car use cause the hospital open spaces to be used as entrance and parking areas. In other words, most of the time, the function of the hospital open spaces and their auxiliary function within the treatment process are ignored and meeting instant needs by rapid solutions becomes the main goal. Based on this problem, the article aims to define open space requirements of the users in densely populated urban settlements and to put forward design principles, targets and methods that could be applicable to various cases.

In the study, Ankara Gazi University Hospital is selected as the case area where open spaces are used as parking lots but are inadequate to meet the open and green space needs of their users and has been going through a spatial process in a manner. The first chapter examines the effects of hospital open spaces on individual health and contribution of idealkent $\odot$ Kent Araştırmaları Dergisi (Journal of Urban Studies) 
these spaces to healing processes. In the second chapter different user groups and their varied open space needs in hospitals are analysed and main functional areas are tried to be defined for each group and design criteria for open spaces are listed according to their needs. In the findings and discussion the deficiencies of open spaces in Gazi University Hospital Area are mentioned, the extent to which the criteria defined in the related literature is analysed, based on the data derived from the questionnaires suggestions are made to remedy the deficiencies observed in the case area. In the conclusion taking the need for open spaces in health care areas and particularly in hospitals of the urban fabric into account, minimum requirements for meeting users' needs are underlined. The article could be inspiring on the hospital administration in making their decisions on designing and utilizing their open space areas after the demolition of the expired buildings in the hospital campus which is on their agenda.

It is possible to cite three main user groups for hospitals and health complexes which serve as public spaces: permanent personnel such as doctors, medical and administrative staff; patients; companions and visitors. Each user group has different needs and therefore develop different modes of utilization. Research conducted on the utilization of open space areas reveal that these areas are mostly utilized by the staff / personnel (individual or group). This is followed by patients and their companions and visitors. Patients without any companion are the group who use these areas the least (Marcus and Francis, 1997, s.311; Epstein, 2013). Defining the needs and modes of utilization for different user groups would underline the need for differentiated designs and would contribute to devising different design criteria.

Although they have similar common functions with public spaces in general, health care open spaces have their own particular functions. Users of the latter by having dynamic and constantly changing profiles requires more than functional and esthetical design but also inclusion of natural assets and landscape features.

Positive contribution of the comfort and healing characteristics of health care areas on the performance of doctors, students and other staff should be taken into consideration besides the other users. Feeling safe and secure, having facilities for physical activity and exercise and interaction with the nature should be set as the primary goals in the design process of relaxation areas. However, achieving these goals spatially may not be sufficient functionally. Making them known by everyone, visually transmittant, accessible for all, enabling their active and passive use, 
providing their lightening, designing them by taking climate effects (sun, wind, rain etc.) and providing their sound isolation can be listed as the other important aspects to be cared for

As stated in the literature properly designed hospital open areas have positive effects on both health and urban areas and this makes these areas to be handled primarily in design and implementation processes. What is important in this process is to deal with the design of open areas together with the design of the buildings in a holistic design approach. Spatial characteristics such as physical and visual accessibility, proximity and intelligibility and settings caring for natural values (sun, trees, flowers, water, shadow, temperature etc.) are basic implementations that could be adopted in these areas.

Being one of Turkey's qualified healthcare institutions, Gazi University Hospital has all the user groups mentioned above and serves in a wide spectrum. Taking is and the diversity of its user groups into account it is vital that its open space areas should be designed to be able to respond the needs of all these users. Questionnaires and interviews reveal that with its present situation hospital open space areas could respond only to certain needs of its users. All the participants declared that they wanted to use these areas primarily for resting and relaxation and that the most urgent problem to be solves as vehicle-pedestrian chaos. Moreover, on the part of the patients creation of places where they can interact with the nature is an important aspect to be dealt with in the renovation process. Therefore, in the design process of open spaces creation of pedestrian oriented places, safety and security feeling, providing physical activity and exercise facilities and creation of relaxation areas enabling interaction with the nature should be set as the prior goals.

All in all, in the creation of hospital areas and their related open spaces, besides the implementation of the principles valid for successful urban public spaces, main requirements necessitated by the function (patient privacy, needs of differentiated users functional spatial relations, hygiene etc.) should also be the main tenets of the design. It should be kept in mind that safe and comfortable use of created places by disabled and disadvantaged users and providing equal access for everyone is important in terms of social equality.

\section{Kaynakça}

Abbas, M.Y. ve Ghazali, R. (2011). Physical environment: The major determinant towards the creation of a healing environment?. Procedia - Social and Behavioral Sciences, 30, $1951-1958$. 
Aksu, Ö. V. ve Demirel, Ö. (2012). Hastane bahçelerinde peyzaj tasarımları: Trabzon kenti örneği. Kastamonu Üniversitesi, Orman Fakültesi Dergisi, 12 (2), 236-250.

Bengtsson, A. ve Grahn, P. (2014).Outdoor environments in healthcare settings: A quality evaluation tool for use in designing healthcare gardens. Urban Forestry E Urban Greening, 13, 878-891.

Desha, C.; Nieberler-Walker, K.; Reeve, A. (2016). Healing gardens: Hospital design using nature to heal and soothe. Landscape Australia, Design, Urbanism, Planning. 24.Nisan.2018 tarihinde https://landscapeaustralia.com/articles/healing-gardens-hospital-design-using-nature-to-heal-and-soothe/\#object-credits adresinden erişildi.

Desha, C., Nieberler-Walker, K., Reeve, A., Jones C. F. (2016). Bench seats in the Lady Cilento Children's Hospital "secret garden" are surrounded by lush tropical vegetation. Landscape Australia, Design, Urbanism, Planning. 24.Nisan.2018 tarihinde https://landscapeaustralia.com/articles/healing-gardens-hospital-design-using-nature-to-heal-and-soothe/ adresinden erişildi.

Epstein, M. (2013). Not all healing gardens deliver as advertised. Health Care Design and Construction, Seattle Daily Journal of Commerce, 03.Mayıs.2018 tarihinde http://www.djc.com/news/ae/12056480.html adresinden erişildi.

Gazete Duvar. 12.Mayıs.2018 tarihinde https://www.gazeteduvar.com.tr/gundem/2018/10/10/gazi-hastanesi-ameliyatlar-devam-ediyor/adresinden erişildi.

Gazi Hastanesi. 10.Ocak.2017 tarihinde http://hastane.gazi.edu.tr/ShowPage.php?p=40f5888b67c748df7efba008e7c2f9d2 adresinden erişildi.

Gormley, T. (2010). The history of hospitals and wards. Healthcare Design, 10(3), 50-54.

Hartig, T. (1993). Nature experience in transactional perspective. Landscape and Urban Planning, 25, 17-36.

Hartig, T., Mang, M. ve Evans G.W. (1991). Restorative effects of natural environment experiences. Environment and Behavior, 23, 3-36.

Huisman, E.R.C.M., Morales, E., van Hoof, J. ve Kort, H.S.M. (2012). Healing environment: A review of the impact of physical environmental factors on users. Building and Environment, 58, 70-80.

Karakaya, B. ve Kiper, T. (2011). Hastane dış mekân tasarımlarının Edirne ili örneğinde irdelenmesi. Tekirdă̆ Ziraat Fakültesi Dergisi, 8(2), 49-64.

LMC Embark (2016). The Healing Benefits Of A Beautiful Property, Landscape and Tree Care, FEB, 05 2016, 24.Nisan.2018 tarihinde https://mchouston.com/blog/healingbenefits-beautiful-property adresinden erişildi.

LOUCKS (2006). Maple Grove Hospital. 24.Mayıs.2018 tarihinde https://www.loucksinc.com/project/maple-grove-hospital-3/ adresinden erişildi.

LOUCKS (2015). St. Joseph's Hospital Healing Garden. 24.Nisan.2018 tarihinde https://www.loucksinc.com/project/st-josephs-hospital-healing-garden/st- jo-

seph s healing garden - night fountains - tertiary page - lower block 6/ adresinden erişildi.

Marcus, C.C. (2007). Healing gardens in hospitals. IDRP Interdisciplinary Design and Research e-Journal, Design and Health, I(I), 1-27.

Marcus, C.C. ve Barnes, M. (1999). Healing Gardens: Therapeutic Benefits and Design Recommendations., NewYork: John Wiley\&Sons. 
Marcus, C.C. ve Francis, C. (1997). People Places: Design Guidlines for Urban Open Space. NewYork: John Wiley \& Sons.

Milano Citta Stato, (2016). Healing Gardens: curare i malati con dei Giardini. 24.Nisan.2018 tarihinde http://www.milanocittastato.it/news/healing-gardens-curare-i-malaticon-dei-giardini/adresinden erişildi.

Mourshed, M. ve Zhao, Y. (2012). Healthcare providers' perception of design factors related to physical environments in hospitals. Journal of Environmental Psychology, 32, 362 370.

Placzek, M. (2013). Water Feature Sculpture For Healing Garden Designs, The Bergan Mercy Medical Center in Omaha, Nebraska. Healing Garden Art and Sculpture, 24.Nisan.2018 tarihinde http://www.healinggardenart.com/2013/10/03/water-feature-sculpture/ adresinden erişildi.

Sachs, N. (2016). Exploring the connection between nature and health, Therapeutic Landscapes Network, Jacqueline Fiske Healing Garden, Jupiter Medical Center, Jupiter, FL. Photo courtesy of Studio Sprout, 24.Nisan.2018 tarihinde http://www.healinglandscapes.org/blog/2016/09/what-is-a-healing-garden/ adresinden erişildi.

Setola, N. ve Borgianni, S. (2016). Designing Public Spaces in Hospitals, NewYork: Routledge. Severtsen, B. (2006). Healing Gardens. 01.Mart.2018 tarihinde https://depts.washington.edu/open2100/pdf/2 OpenSpaceTypes/Open Space Types/healing_gardens.pdf adresinden erişildi.

Spillmann, S. (2017). Medical Center of the Rockies: Stephanie Spillmann, Hospital Gardens that Heal, January 30, 2017, 24.Nisan.2018 tarihinde https://healthysavvyandwise.com/hospital-gardens-that-heal/adresinden erişildi.

SWBR (2015). University of Rochester, Golisano Children's Hospital Healing Gardens, Rochester, NY. 24.Nisan.2018 tarihinde http://www.swbrtest.com/university-rochester-golisano-childrens-hospital-healing-gardens/ adresinden erişildi.

The Dirt, (2013). An Evidence-based Approach to Therapeutic Landscapes. 24.Nisan.2018 tarihinde https://dirt.asla.org/2013/11/27/an-evidence-based-approach-to-therapeutic-landscapes/adresinden erişildi.

Ulrich, R. S. (1981). Natural versus urban scenes: Some psychophysiological effects. Environment and Behavior, 13, 523-556.

Ulrich, R. S. (1984). View through a window may influence recovery from surgery. Science, 224, 420-421.

Ulrich, R. S. (1992). Effects of interior design on wellness: theory and recent scientific research. Journal of Healthcare Design, 3, 97-109.

Uslu, A., Kiper, T. ve Barış, E. (2009). Public health - urban landscaping relationship and user's perceptions. Biotechnol. \& Biotechnol, 23(3), 1399-1408.

Wang, L. (2017). Restorative Healing Gardens take over a concrete garage rooftop in L.A. Inhabitat. Healing Gardens Cedars-Sinai Medical Center, 24.Nisan.2018 tarihinde https://inhabitat.com/restorative-healing-gardens-take-over-a-concrete-garage-rooftop-in-l-a/ adresinden erişildi.

World Health Organization. (2018). 11.Ocak.2018 tarihinde http://www.who.int/hospitals/en/ adresinden erişildi. 
Zaretsky and Associates, 2018, Woodward Healing Garden, 24.Nisan.2018 tarihinde https://www.zaretskyassociates.com/what-we-do-2/portfolio/healing-gardens/ adresinden erişildi.

\section{Teşekkür}

Makale kapsamında değerlendirilen anketlerin yapımında, arazi çalışmalarında, veri elde etme ve arazi haritalarının oluşturulmasında yardımcı olan, Gazi Üniversitesi, Mimarlık Fakültesi, Şehir ve Bölge Planlama Bölümü, 2016-2017 Eğitim Yı1ı bitirme ödevi öğrencim Emre Söylemez'e katkıları için teşekkür ederim.

Dr. Nilüfer Gürer, 1976 Ankara doğumludur. Gazi Üniversitesi Mühendislik Mimarlık Fakültesi, Şehir ve Bölge Planlama Bölümünden 1999 yılında bölüm birincisi olarak mezun olmuştur. Yüksek lisans ve doktora eğitimlerini Gazi Üniversitesi Fen Bilimleri Enstitüsü, Şehir ve Bölge Planlama anabilim dalında yapmış, yüksek lisansını 2003, doktorasını 2009 yıllarında tamamlamıştır. 1999-2000 yılları arasında Tüstaş Sınai Tesisler A.Ş.'de Şehir Plancısı olarak görev yapmıştır. 2000-2017 yılları arasında Gazi Üniversitesi, Mimarlık Fakültesi, Şehir ve Bölge Planlama Bölümünde öğretim elemanı olarak görev yapmış, 2017 yılı Mart ayı itibariyle Akdeniz Üniversitesi, Mimarlık Fakültesi, Şehir ve Bölge Planlama Bölümünde öğretim üyesi olarak göreve başlamıştır. Şehir planlama birinci sınıf proje derslerinde temel tasarım eğitiminin geliştirilmesi çalışmalarının yanı sıra kent planlama, kentsel tasarım, turizm planlaması, rekreasyon alanları planlaması ve tasarımı konularında çalışmaları bulunmaktadır.

Dr. Nilüfer Gürer, She was born in 1976, in Ankara, Turkey. She graduated from Gazi University, Faculty of Engineering and Architecture, Department of City and Regional Planning in 1999, as in the first place in "Honor List" of the department. She finished her MSc. thesis in 2003, and her PhD thesis in 2009, in Gazi University, Institute of Science and Technology, Department of City and Regional Planning. Her working experience was started in 1999 at Tüstas Co. as urban planner, she worked there for 1 year. Between the years 2000-2017, she worked as research assistant and instructor at Gazi University, Department of City and Regional Planning. Since March 2017, she is still working as instructor at Akdeniz University, Department of City and Regional Planning. In addition to develop basic design education in urban planning first class project courses she has publications on following subjects; urban planning, urban design, tourism planning, planning and designing of recreational areas.

\section{Kaynakça Bilgisi / Citation Information}

Gürer, N. (2018). Kent Hastanelerinde Açık Alan Kullanım İhtiyaçlarının Belirlenmesi ve Açık Alan Tasarım İlkeleri. İDEALKENT - Kent Araştırmaları Dergisi, 24, 536-581. 